\title{
ARQUITECTURA TRADICIONAL GANDEIRA NA SERRA DO SUÍDO: A RESPOSTA DUNHA TRADICIÓN
}

\author{
PAULA BALLESTEROS ARIAS
}

\begin{abstract}
Resumen
Expoñemos os resultados dun traballo realizado na Serra do Suído con motivo da aplicación dun plan de Medidas Compensatorias deseñadas para paliar o impacto cultural motivado pola posible implantación dun parque eólico. Os resultados aquí expostos correspóndense coa realización dunha prospección arqueolóxica superficial realizada na mesma serra, con motivo de tentar rexistrar o patrimonio cultural existente. Neste senso atopámonos cunha ampla diversidade tipolóxica de construcións relacionadas coa economía gandeira que hasta fai pouco desenvolvíase na serra de xeito tradicional. Ó tempo, lembramos a figura do etnógrafo galego por excelencia, D. Xaquín Lorenzo, non só por ser imprescindible a consulta da súa obra, senón porque a lectura dos seus artigos referidos ó pastoreo na Serra de Leboreiro axudaron a apoiar a nosa incipiente investigación.
\end{abstract}

\section{Palabras Clave}

Serra do Suído, Arqueoloxía da Paisaxe, Etnografía, Etnoarqueoloxía, Arquitectura Gandeira.

\begin{abstract}
The paper shows the results of a filedwork project carried out in the mountain range of Serra do Suido. The project was part of a plan of Counterbalance Measures designed to compensate the cultural impact caused by the construction of a wind farm. The results shown correspond to a superficial survey developed to record the cultural heritage elements in the Suido range, consisting basically of a wide variety of constructions related to traditional stockbreeding. The range was, until recent time, the space for the development of a series of practices of cattle raising quite particular and specific of some mountain areas of Galicia. Simultaneously the paper recalls the personality of D. Xaquín Lorenzo, the most significant Galician etnoghapher, since his reserach on the cattle rising on the range of Serra de Leboreiro were extremely helpful in the foundations of this piece of research.
\end{abstract}

\section{Key Words}

Serra do Suído, Landscape Archaeology, Etnography, Etno archaeology, Building for Stock. 


\author{
«É como quen tira unha cousa polo río abaixo \\ e non a colle no momento en que a ten á man: \\ despois a auga lévaa e non se volve ver: \\ E eiqui ocorre o mesmo. Esto váisenos» [...].
}

Xaquín Lorenzo en 1979 nunha entrevista feita por Afonso Vázquez-Monxardín

\section{INTRODUCIÓN}

Este artigo recolle parte dos resultados obtidos dun traballo enmarcado dentro do Plan de Inventario e Documentación complementario ó de Estudo de Impacto desenvolvido na Serra do Suído, derivado da posible instalación de xeradores eólicos por parte da empresa Eurovento. Deste xeito, e ante a necesidade de mitigar ó máximo posible o impacto que producirán as implantacións dos xeradores, pretendeuse que esta implantación fose o máis respectuosa posible co patrimonio natural e cultural existente, sendo un dos mellores xeitos facelo a través dun plan de recuperación dese patrimonio e da paisaxe na que se insire. Ese Plan de Recuperación componse de varios subpláns ou fases, sendo un deles o plan correspondente ó inventario e documentación dos elementos culturais da Serra do Suído.

O Plan de Inventario e Documentación, desenvolvido na campaña de verán de 2003, tivo como obxectivo proceder á documentación do patrimonio da cultura material a partir da prospección arqueolóxica superficial, e do patrimonio da cultura inmaterial para acceder ó coñecemento das actividades realizadas na serra, caracterizada por unha orientación gandeira de tradición moi antiga e unha xestión complexa dos recursos animais. A este respecto, neste artigo preséntanse os resultados correspondentes á parte do inventario do patrimonio da cultura material, en concreto das construcións localizadas no ámbito da serra vinculadas ó sistema de explotación gandeira extensiva desenvolvido neste territorio.

A prospección arqueolóxica fixo posible documentar unha grande cantidade de restos arquitectónicos dispersos pola serra que na actualidade se nos presentan como verdadeiros restos arqueolóxicos dos que hai que desentrañar o seu significado. Así foi como se plantexou unha parte do traballo. Na seguinte parte tratamos de ver a maneira máis inmediata de redescubrir o significado desas construcións, o porqué de determinadas formas construtivas ou a funcionalidade de estruturas asociadas, así como tamén coñecer á sociedade que as creou, usou e semantizou un territorio de serra. Afortunadamente esta parte tamén era realizable, pois eramos 
conscientes de que parte da sociedade que lles daba uso aínda estaba viva. A recollida de testemuñas dos habitantes da serra presentóusenos como a única e mellor solución para aclarar os problemas interpretativos que nos podían plantexar os restos materiais. Neste sentido, a Antropoloxía presentouse como unha ferramenta indispensable para recuperar o pasado, antes de que os restos da cultura material se convertan para sempre en patrimonio arqueolóxico, e teñamos que reinterpretar a sociedade que os utilizou.

Deste xeito, a Serra do Suído é un territorio moi amplo onde asta non hai moito tempo desenvolvíase unha intensa actividade económica fundamentalmente gandeira, e como lembranza desta época quedan unha grande cantidade de vestixios arquitectónicos de variada tipoloxía e en distinto grao de conservación. Se a esto unimos ó feito de que temos a sorte de que contamos aínda con xente nos pobos, que na súa memoria tamén garda lembranzas desta época pasada, encontrámonos cun espacio verdadeiramente rico no amplo sentido da palabra. En definitiva, todo o que temos na Serra do Suído son testemuñas dunha cultura e dunha forma de vida que nestes momentos si estamos en condicións de rescatar.

A localización e rexistro dos chozos e demais estruturas arquitectónicas da Serra do Suído, xunto coa recuperación da memoria dos seus habitantes, serviranos para mostrar como era o modo de vida e as costumes imperantes nos concellos limítrofes da serra antes de que se iniciase, a mediados dos anos corenta, o proceso de emigración na zona e, polo tanto, da desestruturación e desaparición da dedicación gandeira, con construcións insólitas, dunha serra galega. Neste senso, consideramos que o rexistro e documentación destas construcións neste momento foi de vital importancia, pois o seu actual estado de abandono e ruína pode levar á súa progresiva desaparición, o que constitúe unha perda importante, xa que estas construcións rurais tradicionais forman parte do noso patrimonio arquitectónico, socioeconómico e cultural, ademais de ser «documentos» da nosa historia rural. E o primeiro paso para a súa revalorización é o seu estudo e posterior divulgación do coñecido.

Con todo, a falta dun estudio da documentación escrita da zona fai que teñamos que expoñer datos illados ó longo do texto, aínda que sabemos que haberá documentación suficiente como para poder facer unha reconstrución etnohistórica documental de toda a zona, dos pobos que facían uso dela e dos señores e estamentos eclesiásticos que tiñan posesións e dereitos de pasto nestas zonas.

Desde o punto de vista teórico, partimos da liña de investigación da Arqueoloxía da Paisaxe, concíndose a paisaxe coma un producto socio-cultural creado pola obxectivación sobre o medio e, en térmos espaciais, da acción social tanto de caracter material como imaxinario. Esta acción social está constituída tanto polas prácticas 
sociais como pola vida social mesma. Neste sentido, podemos definir a Arqueoloxía da Paisaxe como unha estratexia de investigación que comprende o estudo de tódolos procesos sociais e históricos na súa dimensión espacial, ou mellor, que pretende reconstruír e interpretar as paisaxes arqueolóxicas a partir dos obxectos que as concretan (Criado 1999: 5-6). Esta é a liña de investigación principal seguida polo Laboratorio de Arqueoloxía da Paisaxe (LAr) na que se destaca, entre outras cousas, a necesidade dunha interdisciplinariedade doutros ámbitos de investigación para poder chegar a unha completa interpretación non só do obxecto senón do espacio no que se integra.

Neste sentido, no traballo realizado no Suído tomamos man da Arqueoloxía Rural que, xunto coa Arqueoloxía da Paisaxe, pretende descubrir que o medio, a miúdo comprendido como «natural», é un medio histórico no que, en moitos casos, aínda seguimos interaccionando. Especificamente, a Arqueoloxía Rural céntrase no estudo da xenealoxía arqueolóxica e evolución histórica dos elementos da paisaxe rural tradicional, en xeral, (Criado e Ballesteros 2002: 463), da formación do espacio agrario e gandeiro e da evolución das formas de produción, en concreto. Neste estudo tamén integramos a disciplina da Antropoloxía Cultural como ámbito de coñecemento do ser humano e as súas accións no ámbito cultural, económico e social. E, á súa vez, da Etnografía, como o estudo descritivo da cultura dunha comunidade, ou dalgún dos seus aspectos fundamentais, baixo a perspectiva da comprensión global da mesma (Aguirre 1995: 3). Para completar esta interdisciplinariedade, necesaria para levar a cabo un bo traballo de campo e de gabinete, botamos man da estratexia de investigación denominada Etnoarqueoloxía, entendida como unha aplicación máis da Etnoloxía para a reconstrución do pasado, que estudia as relacións entre a cultura material e o resto das manifestacións culturais das poboacións coñecidas a través do rexistro Etnográfico e Histórico, ou ben a través da Etnoloxía e a Historia para, por extrapolación cara o pasado, comprendelas e interpretalas á luz do seu coñecemento no presente (Vázquez 2000: 11).

Para rematar, neste artigo quixemos destacar especialmente a figura de Xaquín Lorenzo (1907-1989), entre outras cousas por ser o referente inmediato e único no ámbito de investigación de Galicia que trata o mundo do pastoreo xunto ás súas antigas construcións. En certo modo, este estudo retoma a investigación etnográfica e o traballo de campo que el fixera no 1933 na Serra do Leboreiro, territorio asombrosamente similar á Serra do Suído en canto á construcións tradicionais e dedicación económica se refire. 


\section{ANTECEDENTES NO EIDO ETNOGRÁFICO}

$\mathrm{Na}$ Galicia da segunda metade do século XIX xurdiron institucións dedicadas a recoller datos da cultura tradicional conservada por labregos, mariñeiros e artesáns. Seguindo a iniciativa dun dos iniciadores dos estudios do Folclore no estado español, Antonio Machado y Álvarez, no ano 1884 foi presentada na Coruña a Sociedade El Folclore Gallego, da que será presidenta Dona Emilia Pardo Bazán. Entre outras actividades feitas pola Sociedade destaca a confección dun primeiro Cuestionario de folclore gallego que consta de 445 preguntas nas que se inclúen os máis variados aspectos da cultura popular. Este afán recompilador seguirá presente nos etnógrafos do século XX e, por suposto, na obra de Xaquín Lorenzo. Outro antecedente desta segunda metade do século XIX ven sendo Manuel Murguía, cunha interpretación historicista dos datos recollidos, dimensión que igualmente herdarán os homes do Seminario de Estudos Galegos (González Reboredo 1999: 59-60).

A recollida da tradición oral rexurde a principios do século XX co interese pola cultura popular e pola historia de Galicia, adquirindo un valor como pegada de identidade. Os membros do Seminario de Estudos Galegos fomentan o desenvolvemento da investigación etnográfica, deixando unha forte impronta na investigación non só arqueolóxica senón tamén histórica e, por suposto, etnográfica.

Neste senso, a obra de Cuevillas e Vicente Risco (direitor da Seizón d'Etnografia do Seminario de Estudos Galegos), conduciron a un achegamento entre a investigación arqueolóxica e a antropoloxía. Este vencellamento plasmaríase no afortunado proxecto de catalogación dos castros galegos promovido desde a revista Nós fundada por V. Risco, publicación que abrangarían os anos 1920-1935, dentro da cal a prospección arqueolóxica xunguíase a unha exhaustiva recolleita das referencias lendarias e tradicións vencelladas ós xacementos (Ayán 2002: 148). Os precedentes a destacar no estudo das lendas en Galicia foron os feitos no século XX desde una metodoloxía científica polos investigadores do SEG Risco, Bouza-Brey, Cuevillas, Fraguas Fraguas, así como polos continuadores desta tradición como Taboada Chivite, Chao Espiña, Leandro Carré.

Por outra banda, Xaquín Lorenzo Fernández, «Xocas», preséntase como referente máis inmediato e principal da etnografía galega, sendo Otero Pedrayo, Florentino Cuevillas e Vicente Risco os seus mestres declarados. Na súa obra, Don Xaquín actúa coma outros etnógrafos do seu tempo, presentando os materiais fóra do seu contexto, pois a meta imperante no momento era a da salvación de formas culturais, a recompilación do dato etnográfico antes de que desaparecese, xa que analiza os fenómenos da cultura como «cousas», sen atender á complexidade dos procesos nas que esas «cousas» se encadran. Pero isto non nos impide recoñecer 
nel un etnógrafo atento a recuperar o dato antes de que se perdese, deixándonos un amplísimo legado que abarca un completo abano de incursións nos diferentes eidos da cultura desde a Arqueoloxía, pasando pola Historia, Lingüística e, fundamentalmente, a Etnografía. É unha obra densa, minuciosa e valiosísima para á nosa cultura galega. Destacar a súa importantísima aportación a Historia de Galicia ${ }^{1}$, editada por primeira vez en Buenos Aires no 1962, e titulada «Etnografía, Cultura Material», síntese de indudable valor sobre as construcións, obxectos, e habilidades dos labregos, artesáns e mariñeiros, así como en multitude de artigos dedicados tanto á cultura material, procurando asociar os obxectos que estudaba coa súa nomenclatura e coas variantes que da mesma se puideran detectar nos diferentes lugares de Galicia (González Reboredo 1999: 64-66).

Ademais da inevitable consulta que supón a obra de Xaquín Lorenzo desde o eido máis puramente etnográfico, para a nosa investigación en particular foi dunha grata sorpresa atoparnos con dous artigos referidos ó pastoreo e ás súas construcións, especialmente dous artigos producto dunha investigación que realizou na serra do Leboreiro, serra meridional ourensá que fai límite natural entre Galicia e Portugal, e que abarca as comarcas da Limia e Baixa Limia máis a parte portuguesa do Peneda-Gerês, e cuxas similitude coa Serra do Suído, desde o punto de vista económico, arquitectónico e da organización social, é bastante asombrosa. «As antigas habitacións de pastores en la Sierra del Leboreiro» publicado en 1947 en Cuadernos de Estudios Gallegos, fai unha descrición dos restos arquitectónicos das cabanas de pastores localizados en Porcarizas, pobo do Leboreiro, e que quedaran ó descuberto por un incendio forestal. Tratábase dun asentamento de pastores utilizado unicamente na tempada de verán, abandonado segundo as súas indagacións no século XVI. O segundo artigo titulado «O pastoreo na Serra de Leboreiro» foi publicado en 1959, nas Actas de Coloquio de Estudos Etnográficos Dr. José Leite de Vasconcelos. Nel expón de maneira concisa a organización social en torno ó pastoreo. Describe a actividade pastoril que alí se desenvolvía, os coidados dos animais, o tempo que botaban na serra, as quendas que se realizaban entre os veciños, etc.

A Serra do Leboreiro, o igual que o Suído é unha zona interior, de media montaña, de dedicación basicamente gandeira con construcións de diversa índole vin-

\footnotetext{
${ }^{1}$ Obra dirixida por Otero Pedrayo, editada por primeira vez en Buenos Aires no 1962, na que se reúnen tres dos clásicos estudosos da nosa terra: Otero Pedrayo aporta o estudio xeográfico, Vicente Risco o rexistro da cultura inmaterial, todo o referido ás lendas, refráns, cantigas, etc., tomo que leva por título A Cultura Espiritual e Xaquín Lorenzo fai o tomo dedicado ó ámbito etnográfico, que leva por título A Cultura Material.
} 
culadas a esta actividade de pastoreo das que xa nos deu conta Xaquín Lorenzo, así como da súa organización que, segundo as pesquisas de D. Xaquín, desenvolvíase do mesmo xeito que nas brañas e alzadas asturianas. Seguindo a pegada do publicado desta zona, puidemos saber que esta é unha rexión moi rica en muíños e hórreos como por exemplo en Olela, lugar do concello de Entrimo, onde se contabilizaron máis de 70 hórreos. A organización era comunal no concello dos Muíños, Comarca da Baixa Limia. É reseñable o feito de que nos pobos de alta montaña, como por exemplo Gundemil e Requiás, aínda se conserven as costumes de antano onde seguen funcionando as comunidades agrarias, o que conleva que cada veciño teña asignado unha tarefa: acompañar ó gando, tecer, facer unha fornada de pan, etc., organización comunal que lembra a organización que ata fai cousa de non máis de medio século desenvolvíase tamén nos pobos do Suído.

\section{Desenvolvemento do traballo}

Ante os abundantes restos pertencentes á arquitectura tradicional de montaña, e ante a necesidade de achegarse a coñecer unha actividade vinculada estreitamente co medio natural, así como ás persoas que a levaban a cabo, ou que alomenos lembran o momento no que o pastoreo constituía a riqueza básica destes pobos, leváronse a cabo unha serie de accións que permitiron recuperar do esquecemento este medio natural e a actividade económica nel desenvolvida.

Para levar a cabo esta recuperación fíxose inevitable o traballo de campo, a visita directa e o contacto coa poboación. Considerouse necesario proceder á prospección superficial como medio para a realización da documentación exhaustiva das formas e elementos da paisaxe, referíndonos ás construcións realizadas para satisfacer as necesidades básicas do pastoreo ou da subsistencia na serra como son os chozos, curros, sesteiras, valados, foxos de lobo, etc. Deste xeito, as ruínas e os restos arqueolóxicos implican, xunto á súa dimensión tecnolóxica, unha dimensión socio-económica, política, relixiosa e artística que non hai que esquecer (Trías 1995: 168). Por iso, esta cultura material é unha parte fundamental para o coñecemento da comunidade que a levantou, usou e conservou.

Ó tempo, esta observación foi complementada coa realización dunha enquisa etnográfica, é dicir, coa conversación cos protagonistas culturais como comunidade posuidora duns coñecementos e saberes por transmitir. Comprender a vida que non hai moito se desenvolvía na serra é unha tarefa urxente, pois córrese o perigo de que se perdan todos os aspectos que a caracterizaban. Por iso, levar a cabo entrevistas na que se favorece o diálogo é o único modo de recuperar esta actividade hoxe en día desaparecida. Considerouse importante facer o inventario da toponimia menor co seu conseguinte análise. Xunto coa enquisa consideramos necesario pro- 
ceder ó estudo da microtoponimia que nos orientara cara o coñecemento do medio por parte dos seus habitantes, sobre a variedade paisaxística, a riqueza léxica, os usos do solo, as lendas, etc. Deste xeito, fixemos unha procura fundamentalmente da microtoponimia do Suído, abarcando unicamente o territorio da serra sen chegar as zonas de val ou as poboacións próximas á serra, facendo unha clasificación segundo a tipoloxía do nome á que fan referencia.

\section{A localización xeográfica}

A área obxecto de estudo emprázase na parte alta da Serra do Suído, sistema montañoso de orientación $\mathrm{N}-\mathrm{S}$, situado no sector sur da «dorsal meridiana galega». Esta serra conforma o límite natural entre as provincias de Pontevedra e Ourense, onde limitan os concellos pontevedreses de A Lama, Fornelos de Montes e O Covelo. E na banda ourensá sitúanse os concellos de Beariz e Avión (Lámina. 1).

A orixe da serra é precámbrica e paleozoica. Trátase de bloques levantados tras a súa fracturación, modelados sobre granitos en liñas de cume e sobre xistos nas zonas máis baixas, caracterizándose polos seus fortes desniveis topográficos, coroados por diferentes superficies de erosión, así como por unha rede de fallas de dirección N-NE, S-SW que determinan a alternancia serra-val. Desde o punto de vista xeográfico, este sistema montañoso forma parte da dorsal meridiana que divide o territorio galego de norte a sur. A Serra do Suído deixa ó $\mathrm{E}$ a bacía do Miño, polo S ábrese cara os vales de Mondariz, o Monte Pedroso, e os montes de Faro de Avión; cara o $\mathrm{N}$ ten a súa continuación a través dos Altos do Paraño coa serra de Testeiro; polo $\mathrm{W}$ ábrese cara o mar, baixando polas bocarribeiras e vales, xa na provincia de Pontevedra. Acada unha altitude media de $989 \mathrm{~m}$, rexistrándose as súas cotas máis elevadas nos montes de Cotos Cornudos (1032 m), Coto Minuto $(1055 \mathrm{~m})$ e Millao $(1024 \mathrm{~m})$. En canto á súa petrografía, destaca o granito, formando grandes penedos, denominados bolos graníticos. Tamén abunda o gneis, o seixo, «ollo de sapo» e o xisto.

As características da poboación dos concellos comprendidos nesta zona resúmense na dispersión favorecida pola configuración do relevo, a altitude e os microclimas que se forman nas vertentes de diversa insolación e aporte hídrico. Hai unha disgregación que comprende desde os agrupamentos maiores, as cabezas parroquiais, ata os máis pequenos de oito a doce casas (Bejarano 1986: 16). A economía é agrícola e gandeira. Ata non fai moito tempo, nas zonas de montaña atopábamos un interese maior da gandería que estaba a producir o excedente comerciable, sendo a agricultura o complemento. Quizais esta balanza agora está invertida ou igualada. De tódolos xeitos, o sector primario é o que ocupa ó maior número de persoas. A economía agrícola baséase na explotación do campo desti-

Cuadernos de Estudios Gallegos, Tomo LI, Fascículo 117, Santiago 2004. (Págs. 9 - 48) 


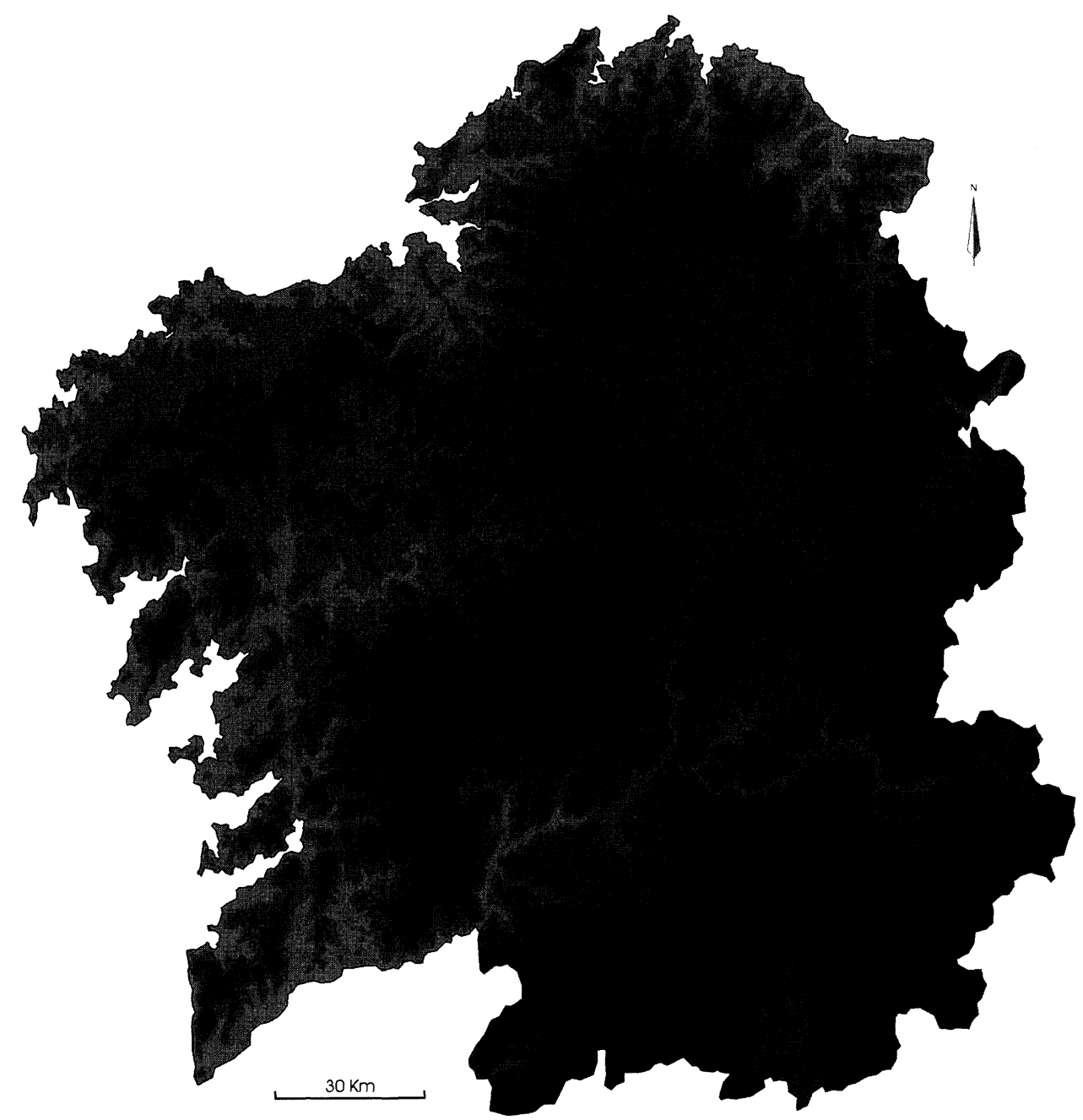

Lámina 1.- Mapa de situación da Serra do Suido no contexto de Galicia.

nada á autosubsistencia e ó autoconsumo, do que só se comercializa unha pequena parte. A paisaxe agraria evolucionou moi pouco, mostrando unha morfoloxía de dominio de parcelas de cultivo moi pequenas (unha porcentaxe moi alta, máis do $99 \%$, son menores de $0,5 \mathrm{Ha}$ ). Presentan formas moi irregulares, separadas normalmente por valos ou por marcos. A zona cultivada limítase ás vertentes de algúns vales situados en torno ós núcleos de poboación. En 1972 a superficie labrada representaba o $6,7 \%$ da superficie total aproveitable, mentres que a monte se dedicaba o $93,2 \%$, onde a maior parte era monte baixo dedicado a pastos. 
A emigración xoga un papel importante na economía destes municipios, especialmente os de A Lama e Avión, sobre todo nas décadas que seguen á Segunda Guerra Mundial. Nun principio se dirixiu cara a Portugal, e posteriormente cara a países americanos como Brasil, México, Venezuela, Arxentina ou Panamá, xa con un caracter definitivo. A finais dos sesenta, a dirección que toma a poboación emigrante é a da Europa industrializada onde se vive o «boom do desenvolvemento». Esta poboación emigrante normalmente sole pasar o mes de vacacións nos municipios os que pertence, por iso durante o verán estes municipios adquiren certo dinamismo social. Pola contra, durante o inverno se produce un baleiro humano destacable.

\section{Marco histórico e desenvolvemento da actividade gandeira}

O nome da Serra do Suído fai referencia á familia dos mamíferos omnívoros á que pertencen o cocho e o xabaril. Se cadra, o topónimo fai referencia á abundancia deste animal en maior número que en época actual. A actividade dominante nos pobos en torno á serra é unha agricultura de autoconsumo, complemento da gandería que preferentemente se desenvolvía na serra en forma de pastoreo libre. De feito, a Serra do Suído é unha zona gandeira de tradición antiga, practicada alomenos desde época medieval, e que seguía en vixencia ata fai uns 40 anos.

Como xa se apuntou anteriormente, desde o punto de vista xeolóxico a serra caracterízase por unha alternancia de serra-val onde, xunto coas chairas, dotan a este territorio de múltiples espacios idóneos para o desenvolvemento dunha gandería extensiva, sobre todo en época estival, xa que debido á abundancia de recursos hídricos sempre hai zonas de pasto fresco. Normalmente o gando vacún ${ }^{2}$ pastaba na serra na época estival mentres que, no inverno, debido á crueza das condicións climáticas, o gando se mantiña nas leiras próximas ás aldeas. Nestas montañas da serra, que estiveron cheas de cabezas de gando no seu tempo, consérvanse restos de habitacións de pastores que reciben o nome de chozos, habitáculos de pequenas dimensións caracterizados pola súa adaptación ó medio e ás necesidades da explotación gandeira, así como distintas estruturas de diversa índole que evidencian un pasado de intensa actividade na serra. $\mathrm{O}$ gando vendíase nas aldeas fundamentalmente a carniceiros ou tratantes como intermediarios. Tamén se comerciaba co leite, queixos, e outro tipo de produtos derivados como son as peles e, fundamentalmente, o coiro, de feito, no concello de Avión rexistramos a existencia de dúas curtidurías que daban servizo a este comercio en alza.

\footnotetext{
${ }^{2}$ A xente das aldeas utilizan o término de res para referirse ó gando ovino e caprino, gando para o vacún e bestas para o equino.
}

Cuadernos de Estudios Gallegos, Tomo LI, Fascículo 117, Santiago 2004. (Págs. 9 - 48) 
Desde o punto de vista histórico sabemos, pola consulta dalgún documento e, sobre todo, pola información obtida a través das enquisas etnográficas realizadas con motivo deste traballo, como se desenvolvía a actividade gandeira na serra, ou como se organizaban as comunidades dos diferentes pobos próximos á serra onde funcionaba unha organización comunal para o coidado do gando, para establecer as quendas de pastoreo, facer as construcións vinculadas a esta actividade, facer tarefas de mantemento, etc. Fundamentalmente, ata fai cuestión de pouco tempo, no concello de Avión había dous sistemas diferentes de quendas para o coidado do gando, adoptados segundo as necesidades de cada comunidade. O sistema de garda funcionaba cando unha comunidade lle pagaba a un pastor, o chamado ghandeiro, ou recentemente tamén denominado pastor alquilado, para que coidase do gando durante toda a estación de verán. Durante ese período o chozo era o lugar de residencia do pastor. Outro sistema de quenda era o denominado como a rolda. Tratábase dunha quenda diaria e rotatoria levada a cabo entre os diferentes integrantes da comunidade para o coidado do gando, tendo o seu relevo nas horas da posta do sol, despois de muxir as vacas, polo que o que saía da quenda levaba a leite para o pobo e o que subía levaba un feixe de palla para as crías do gando. Noutros sitios da serra cada dono facíase cargo do seu propio gando, aínda que descoñecemos se esto foi unha evolución dun antigo sistema comunitario que tornou en coidados individuais, como ven sucedendo na actualidade.

Cara o 1850-1860 o Suído era unha fonte de vida para os pobos de cada lado, o nacente de Ourense e o poñente de Pontevedra. Aquí pastoreaban no verán moitísimas cabezas de gando vacún, cabalar e lanar. Recollíase o toxo, a leña, cultivábase o centeo, era zona de caza abundante, así como tamén era sitio de paso frecuente por onde transcorrían camiños de diversa índole usados por arrieiros e comerciantes. Ó tempo, e pola documentación consultada ata o momento, desde antigo a serra funcionou de límite de dúas provincias. Os documentos remóntannos á época na que os condes de Ribadavia, por parte da zona de Ourense, e os de Soutomaior, pola de Pontevedra, loitaban e preiteaban, a fin de precisar a súa xurisdición. Esta zona sufriu unha continua variación de xurisdicións e de precisión nos seus límites. Na época moderna reproducíronse estes conflitos entre os pobos, para marcar os pastos que correspondían a cada chozo e, outras veces, para fixar os límites de cada administración provincial. A configuración xeográfica da serra fixo difícil este cometido, xa que a sucesión de chairas e de elevacións dá lugar a unha paisaxe bastante homoxénea. Se recorría a pintar as pedras mais destacadas, ou a facer algún sinal, o que servía ós pastores como referencia. A «laxa branca», a «Pedra dos números», etc., fixaban as zonas de pasto. En torno ós chozos tamén había enfilacións de pedras que eran outra referencia. A Verea de Santo 
Domingo, tamén chamada Camiño Breeiro, camiño tradicional que percorre a serra de N-S, servía ó mesmo tempo como límite provincial (Bejarano 1986: 22). Segundo Fernández Pintos (2004) esta ruta era frecuentada por arrieiros que, ó abrigo destes inhóspitos paraxes, trataban de eludir o pago de portazgos das mercancías que transportaban.

Outro dato do que dispoñemos procede de Avión. Durante a época feudal, a súa historia vai ligada a diferentes señoríos laicos e relixiosos que controlan o seu territorio. A finais do século $\mathrm{X}$, a igrexa máis antiga do municipio, Abelenda, pertencía á orde militar do Temple. Por outra banda, Sta. María de Couso formaba parte da antiga xurisdición do Mosteiro de Melón e conserva, no lugar denominado O Penedo, restos do seu antigo cárcere. Durante a Idade Media o maior protagonismo exérceo o señorío dos Sarmientos, Condes de Ribadavia, instaurado en 1315. Estes exerceron un dominio total sobre a antiga xurisdición de Avión, que comprendía as ferigresias de Avión, Abelenda, Amiudal, Córcores, Nieva, Couso (compartida co Mosteiro de Melón) e Barroso, onde se conserva nun dos laterais da igrexa un escudo pertencente ós Condes de Ribadavia. Todas elas estaban obrigadas a pagar un tributo denominado «fumaza» o «fogaza» que, a pesar de ser abolido por sentencia da Real Audiencia de 1812, se mantivo ata o ano 1837, ano en que é suprimida definitivamente por Isabel II, ante a negativa dos veciños a seguir pagándoo (Caeiro 1993: 76). Así mesmo, Avión destacou no sector agrícola e gandeiro, xa que, segundo as fontes, era considerado como «o celeiro do Ribeiro»; de feito, así o testemuñan os máis de 700 canastros, 100 muíños contabilizados, e os 75 fornos de pan comunais existentes en cada unha das aldeas deste concello de Avión.

\section{Riqueza patrimonial da zona}

A realización dos traballos de prospección arqueolóxica deron como resultado a localización e rexistro de grande cantidade de xacementos arqueolóxicos que completan un amplo abano de períodos culturais, desde o Paleolítico, coa aparición de pequenos abrigos rochosos, emprazados en pequenas dorsais protexidas dos ventos dominantes e que presentan unhas condicións mínimas de habitabilidade, ata varios monumentos tumulares datados no período Neolítico, citados xa desde os anos 50 na bibliografía arqueolóxica ${ }^{3}$, castros na zona de val, etc., e construcións

${ }^{3}$ Filgueira Valverde, J. e García Alén, A. 1977. Inventario de monumentos megalíticos. Fundación Pedro Barrié de la Maza, XXXI. Filgueira Valverde, J. e García Alén, A. 1959. Adiciones a la carta arqueológica de la provincia de Pontevedra, XIII: 29. Pontevedra.

Cuadernos de Estudios Gallegos, Tomo LI, Fascículo 117, Santiago 2004. (Págs. 9 - 48) 
de época histórica relacionadas os explotación gandeira. Por outra banda, estas prospeccións deron como resultado a aparición de evidencias de conxuntos de materiais adscribibles a épocas pertencentes ó Paleolítico Superior e/ou Epipaleolítico, relacionados con áreas de actividade de grupos de cazadoresrecolectores, así como tamén gravados de época prehistórica e histórica.

Ó tempo, a potencialidade etnográfica da zona é altísima, tanto a nivel relixioso (igrexas, via crucis, cruceiros, cruces, petos de ánimas, etc.,) como no ámbito civil, no que se refire á conservación das vivendas tradicionais, así como ás construcións adxectivas asociadas ó modo de vida rural tradicional, como son hórreos, alpendres, eiras, muíños, represas, etc.

Pero, sobre todo, hai que destacar a presencia de determinadas construcións localizadas no propio ámbito da serra relacionadas coa existencia dun sistema de explotación gandeiro de carácter extensivo que ven representar a actividade principal desenvolvida polos pobos da serra, e cuxo referente material principal son os chozos ou refuxios de pastores que, polas súas características constructivas, son elementos singulares da Serra do Suído. Xunto a estes refuxios atopamos espacios para albergar ás crías do gando, ou distribuír e gardar os animais chamados cortellos, curros, sesteiros; construcións destinadas á caza de animais, depredadores como son os foxos de lobo, ademais dos valos existentes na serra para delimitar espacios destinados ó cultivo de cereais ou a outro tipo de usos (Lámina 2).

\section{CONSTRUCIÓNS PARA O PASTOREO: OS CHOZOS E A SÚA ARQUITECTURA}

As construcións descritas a continuación móstrannos unha relación entre a arquitectura e o medio no que se atopan. Destas, non nos interesa tanto a época de construción como as súas características construtivas e funcionais, ou o modo e o método de solucionar unha serie de dificultades que impón este medio agreste para poder levar a cabo unha economía gandeira (Lámina 3).

\section{Os chozos de pastores}

Os chozos son unhas construcións pétreas singulares que servían para o resgardo dos pastores que coidaban do gando nas zonas altas da Serra do Suído que, xunto coas construcións menores que normalmente aparecen no entorno inmediato, como son os cortellos e mais os curros, constitúen unha unidade de explotación gandeira (Lámina 4). Estas construcións son parte integrante da economía campesiña, aínda que só fose para desprazamentos temporais en determinadas épocas do ano, é dicir,

Cuadernos de Estudios Gallegos, Tomo LI, Fascículo 117, Santiago 2004. (Págs. 9 - 48) 


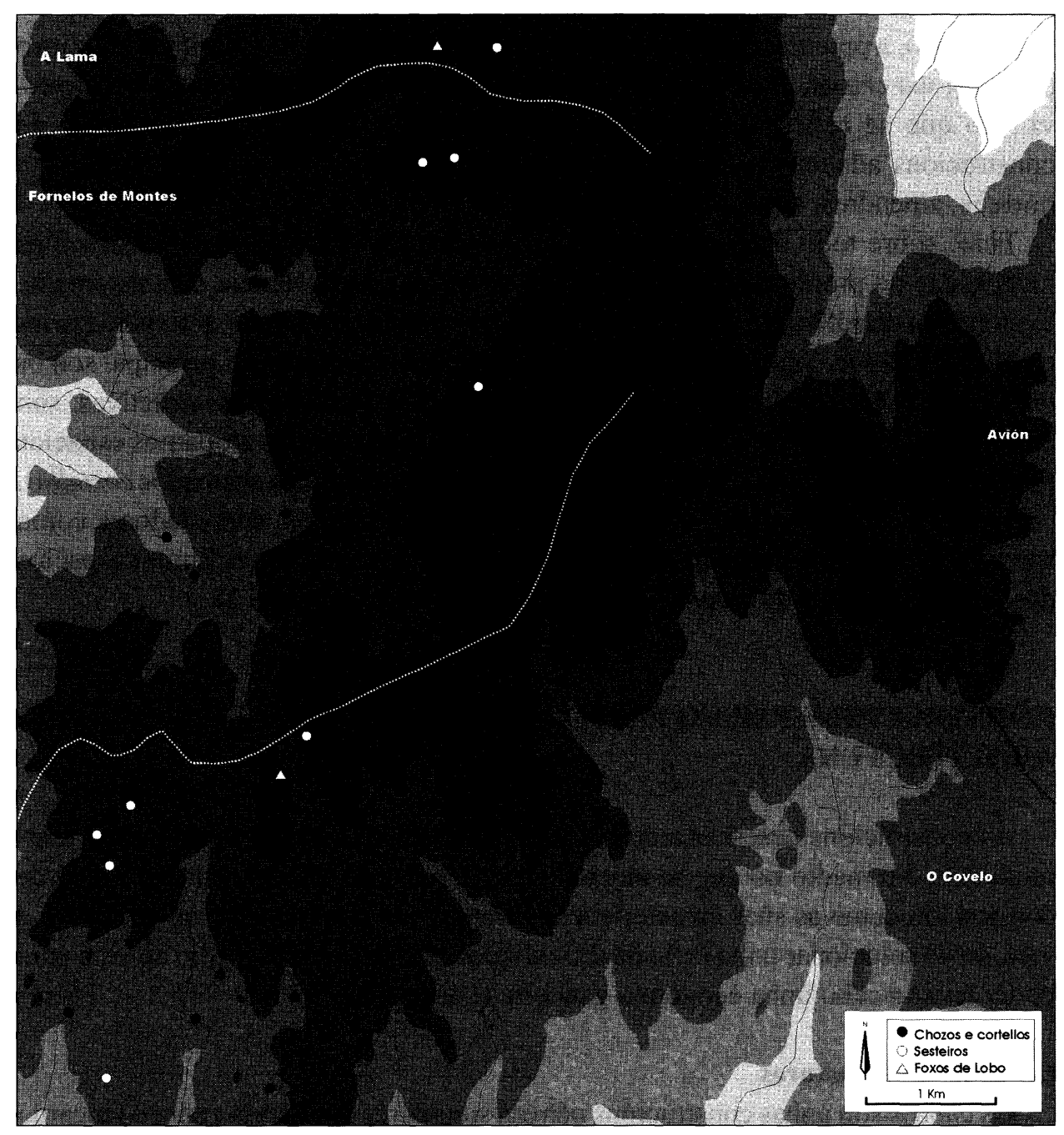

Lámina 2.- Distribución das diferentes construccións para o pastoreo na área de estudio. 


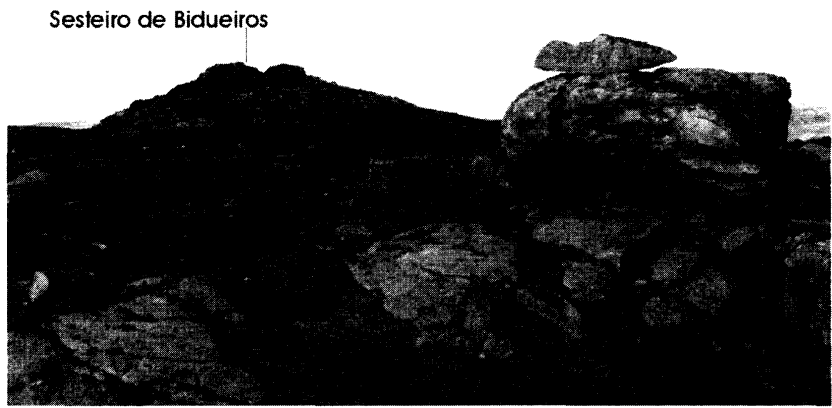

Chozo de Bidueiros
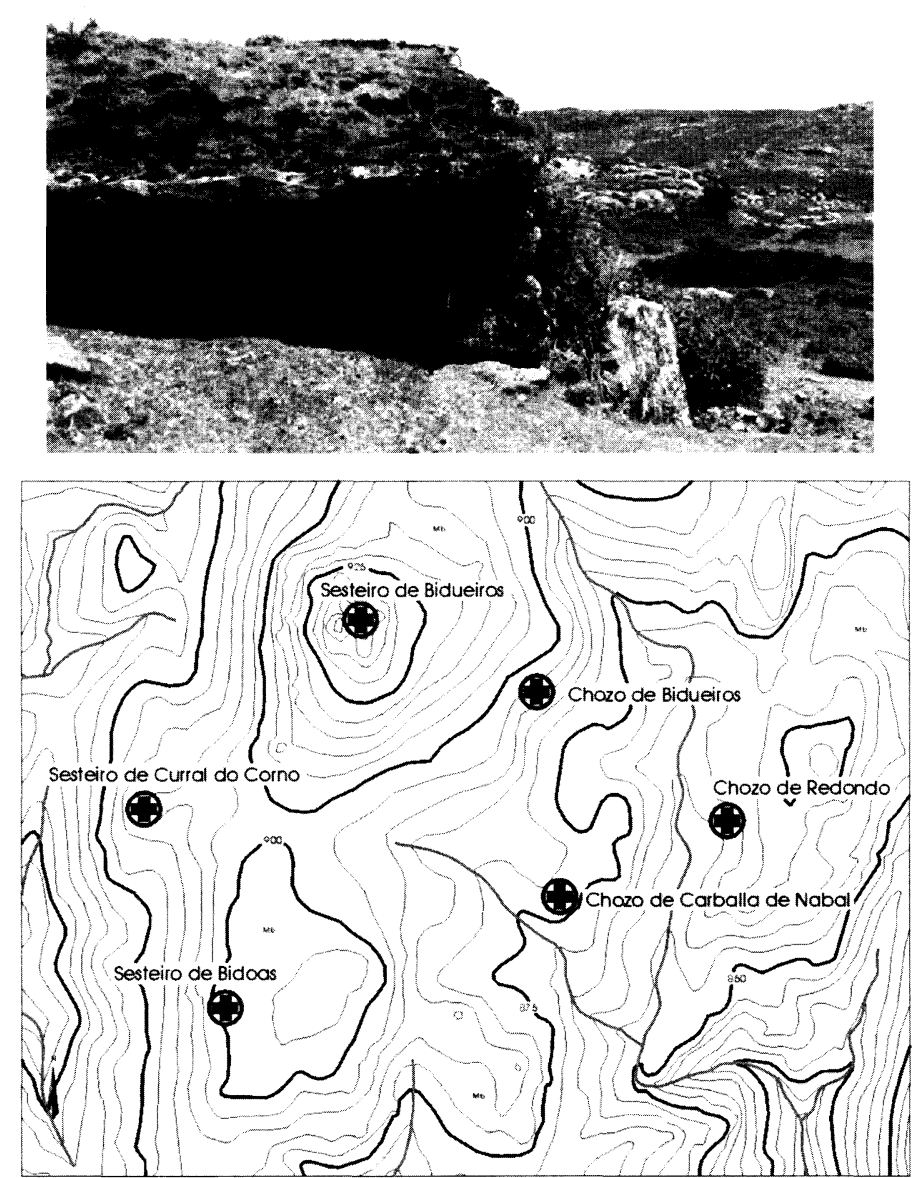

Lámina 3.- Localización e distribución de chozos e sesteiros na zona de Bidueiros.

A selección das formas da paisaxe e a conseguinte distribución dos elementos arquitectónicos, da lugar a un espacio semiantrópico deseñado para usos gandeiros. 


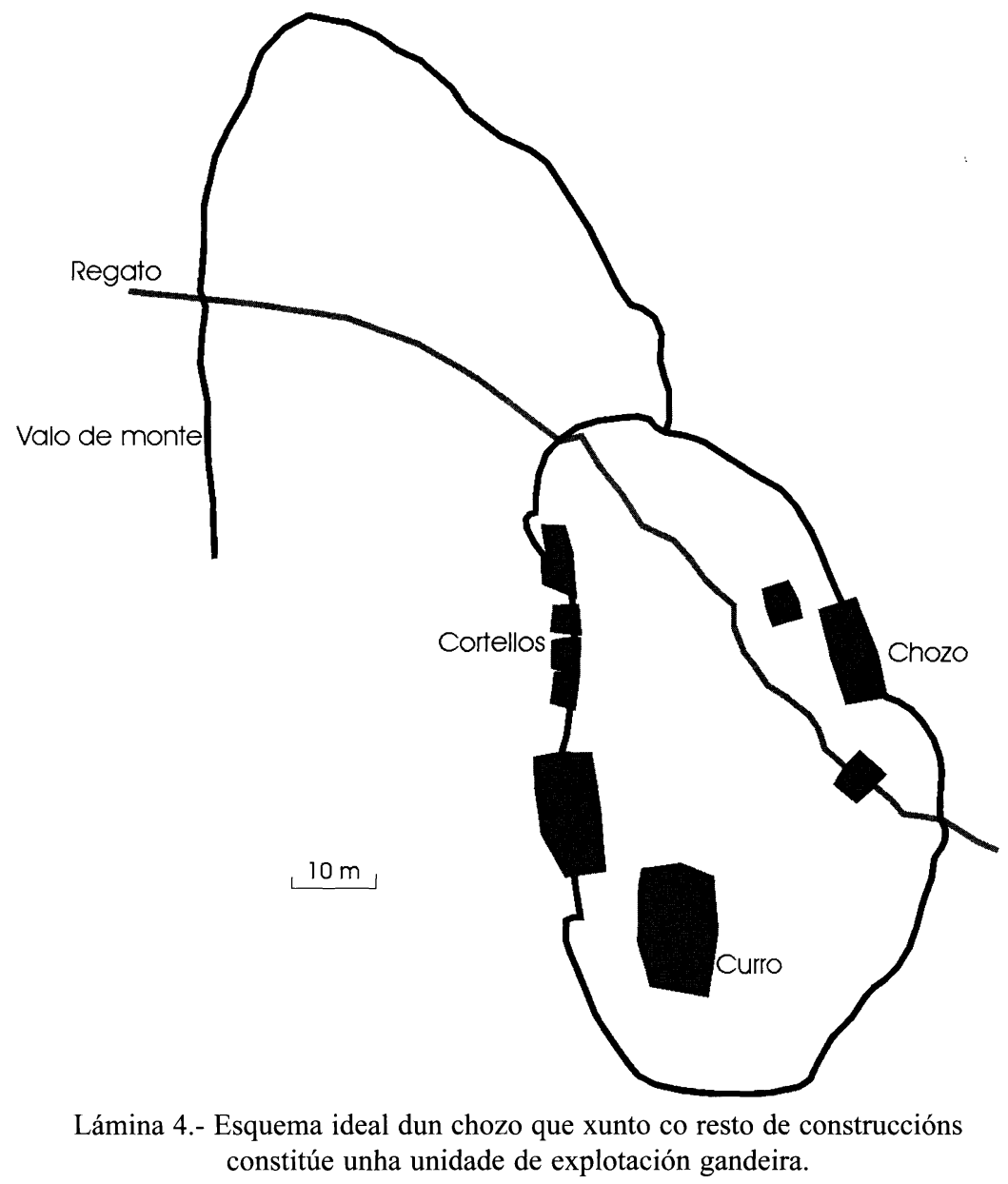

refuxios temporais que só tiñan ocupación continuada durante os períodos estivais. No caso concreto do Suído estes chozos son de propiedade comunal, de xeito que, como norma xeral, cada aldea tiña o seu chozo.

En térmos xerais, nalgúns casos redúcense a simples refuxios naturais, grutas ou covas, ás veces mellorados con cerramentos frontais de cachotería co fin de aumentar a súa habitabilidade, dispersos polas áreas dos mellores pastos, unhas veces illados e outras agrupados en pequenos poboados, do tipo citado por Xaquín Lourenzo nos seus traballos sobre as antigas habitacións dos pastores e o pastoreo na Serra do Leboreiro, onde había lugares de verán e de inverno, trasladándose os veciños con tódolos seus trevellos, incluso coas portas das casas (Lorenzo 1959: 
2). El describe tres tipos de construcións: as chamadas guritas dos mouros, nome que reciben os restos das cabanas cuxa planta é cadrada ou rectangular, illadas unhas das outras; a casiña do rei, que consiste nunha gran rocha cunha das súas caras planas, a que corresponde ó norte, en cuxo borde superior hai unha serie de escotadas feitas para asentalas vigas. Paralela á parte plana da roca elevaríase unha parede na que se apoiarían as vigas, pechando finalmente o teito con palla ou terra dando lugar a unha choza. Por último estarían as tapadas dos mouros, extensións de maior ou menor tamaño, acoutadas por medio de pedras grandes e xustapostas (Lorenzo 1947: 349-50), que veñen ser os currais característicos das serras con explotación gandeira.

Construídas cos materiais existentes nas proximidades e utilizados case no seu estado natural, estas cabanas, no seu estado elemental, limítanse a uns cerramentos laterais construídos seguindo a pendente do terreo, no que as veces se incrustan, levantados cunha groseira cachotería en seco, de xisto ou gneis. No caso dos chozos da serra do Suído, hai un predominio da planta rectangular ou cuadrangular, con dimensións variables, nalgúns casos en torno a vinte metros cadrados, e están construídos mediante bloques e lousas de gneis e granitos, que proliferan na zona, sen utilización de argamasas. Danse varios tipos de cubertas sendo a máis recorrida a de dobre vertente, e consiste nun laxeado de pedras de granito ou xisto colocadas sobre unha estrutura de pedra alintelada sobre os muros laterais, e que se completa mediante unha cubrición de terróns, que ademais de integrar á propia construción no medio serve de illante térmico. É de resaltar o caso curioso e único dos chozos localizados na zona da serra pertecente ó concello de Avión, coa cuberta de dobre vertente sobre arcos de medio punto. Tamén hai cubertas de lousas organizadas en falsa cúpula. Nalgúns casos, e dependendo da posición topográfica que ocupen os chozos, na fachada posterior hai unha serie de lousas fincadas no chan que posiblemente tiñan como fin impedir as filtracións de auga pola parte máis en contacto co escarpe da ladeira.

No exterior, cunha única porta de entrada alintelada, podemos destacar a existencia de pousadoiro e bancos corridos apegados á parede. Algúns chozos teñen gravados no lintel da porta, na lumieira, no seu interior ou ben no exterior, sendo os motivos máis recorrentes as fechas, cruces ou outro tipo de sinais que se poderían identificar como marcas de canteiro.

Asociados a eses chozos e, no entorno dos mesmos, localízanse outras construcións menores, como son as curreiras ou currais (peches para xuntar o gando), ou os cortellos. Xaquín Lorenzo denomina ós currás, ós anacos de monte, con bos pastos, que segundo el, puideron estar vedados por muros de pedra, e dentro destes currais estarían as chamadas «casoupas dos mouros», nomeadas 
algunhas veces como «tapadas dos mouros». No curral atopábase unha casoupa feita con pedras e cuberta con lanchas ou terróns, nas que os pigureiros (nome que reciben os pastores no territorio portugués e máis no Xurés) pasaban a noite.

"As casoupas dos currás, son por veces mellor feitas; na cume do Leboreiro, en Porcarizas e na Ramallosa, ainda se poden ollar as ruinas das casoupas que lembran de xeito sorprendente as casas das nosas citánias» (Lorenzo 1959: 2).

Estas habitacións temporais tamén se atopan nas penichairas da Galicia oriental, no concello de Navia de Suarna e en Raio, aínda que aquí chámanlle «alzadas», dato que nos recorda ás habitacións dos vaqueiros asturianos (Rodríguez 1996: 33).

\section{Aproximación cara unha tipoloxía de chozos no Suído}

Como xa se comentou en apartados anteriores, na prospección efectuada pola serra localizouse unha grande variedade de construcións e demais estruturas que evidencian a intensa actividade gandeira levada a cabo na Serra do Suído ata hai pouco máis de medio século. Estes traballos de prospección e, sobre todo, a enquisa etnográfica realizada e as indicacións dadas pola xente do lugar permitíronnos localizar unha trintena de chozos $^{4}$ cos seus correspondentes cortellos, currais, e demais estruturas feitas para albergar e distribuír o gando.

No que toca ó emprazamento, repítese unha serie de constantes naturais que propiciaron o establecemento das zonas de pastoreo. Todos os chozos localizados están rodeados de terreos aptos para o repouso do gando, cubertos de abundantes pastos con múltiples rexurdencias de augas, por seren lugares de nacemento ou da cunca de recepción de múltiples regatos que discorren pola montaña. O emprazamento atópase na ladeira do nacente, arredor dos novecentos metros de

${ }^{4}$ En Avión localizáronse os chozos de Mangüeiro, Rodeiro, Abelenda, Oroso, San Vicente, Cernadas, San Xusto (reconstruídos e recuperados polo Obradoiro de Emprego «Os chozos») e os chozos de Amiudal, Mouriscados e Carixa. No concello de O Covelo rexistramos os chozos de Portela das Travesas, Bidueiros, Redondo, Carballa de Nabal, Campo, Piñeiro, Fofe, Chambeiro e Penouzos. Finalmente, no concello de Fornelos de Montes, o chozo de Cabañillas, Silvares, dous chozos no Curral de Vilán, tres no Curral de Forzáns e varios sen determinar no Curral de Campolongo. Sabemos da existencia de tres chozos máis no concello de Avión, o Chozo de Boeixas, o Chozo de Beresmo e un terceiro no Campo de Abelenda. Deles só se supón a ubicación, xa que están totalmente derruídos, estando os seus cimentos ocultos pola abundante vexetación circundante produto do abandono. En Abelenda hai un reconstruído, pero pola enquisa realizada soubemos da existencia dun segundo do que só quedarían os cimentos. $\mathrm{O}$ abandono deste chozo deveuse a que deixou de ser necesario ó diminuír as cabezas de gando e, polo tanto, cun chozo bastaba para albergar ás persoas que o coidaban. Disque que a reconstrución do chozo que se conserva en Abelenda levouse a cabo coas pedras procedentes das ruínas do peor conservado. 
altitude, sempre resgardándose dos ventos do norte, aproveitando, nalgúns casos, a caída da ladeira para cimentar a construción.

$\mathrm{O}$ rexistro de todas estas construcións na serra do Suído permite facer unha primeira aproximación cara as diversas tipoloxías de chozos existentes na serra. A elección dun tipo ou outro quizá representan:

- Estadios de ocupación de diferentes épocas.

- Distintos momentos de construción coas consecuentes ampliacións e remodelacións realizadas ó longo do tempo que estiveron en uso.

- Tipo e calidade do material local, así como diferente tratamento e disposición.

- Diferentes necesidades das comunidades que optaron por construír estes chozos, etc.

Aquí nos atopamos desde as formas máis simples e elementais de construción, nas que se aproveitan fundamentalmente os materiais locais, tal e como se atopan na natureza, ou con calquera lixeira feitura, ata construcións algo máis elaboradas. En termos xerais, e tras unha primeira valoración dos restos existentes, podemos facer unha clasificación preliminar dos diferentes tipos de refuxios atopados na serra. Distinguiremos entre abrigos naturais, semi-naturais e artificiais nas súas formas elementais, xa que veñen a constituir as formas primarias, mais remotas e máis simples da vivenda humana (Lámina 5). Nos tempos prehistóricos eran locais de habitación normal, permanente ou estacional. Co tempo foron abrigos temporais ou ocasionais xeralmente relacionados con determinadas actividades, fundamentalmente co pastoreo (Veiga de Oliveira 1994: 12).

\section{Abrigos naturais}

Abrigos debaixo da rocha, de grandes laxes ou penedos encaixados uns sobre outros, deixando un espacio protexido para o resgardo das persoas ou dos animais, preferentemente orientados cara o sur ou o leste.

O caso máis representativo sería o do Abrigo de Valdohome. Trátase dun conxunto de bolos graníticos que, pola súa morfoloxía e distribución, conforman unha serie de espacios protexidos que presentan condicións favorables de habitabilidade. Nestes espacios observouse ademais unha potencia de solo susceptible de albergar restos dunha posible ocupación dos mesmos, de feito foi documentado un conxunto de material lítico significativo, presumiblemente de época paleolítica. O seu emprazamento espacial vincúlase coas zonas húmidas, perfectamente acoutadas, nas que o gando acude hoxe en día para pacer e beber polo que, facendo unha extrapolación destas condicións, podería tratarse de zonas aproveitables para a 
realización de prácticas cinexéticas. Neste caso poderíamos estar ante unha ocupación dun refuxio sen modificación que pode representar ós primeiros estadios de ocupación da serra.

\title{
Abrigos semi-naturais
}

Denomínanse así ós abrigos naturais mellorados e arranxados para un mellor resgardo e habitabilidade do espacio abrigado. Pechados por paredes de pedras soltas sen ningún tipo de argamasa, están ó nivel do chan sempre por debaixo do nivel natural. A planta destes chozos vai desde as formas ovaladas ás redondeadas. Neste apartado englobaríanse os chozos localizados fundamentalmente no concello de O Covelo: Chozo de Campo, Chozo de Piñeiro, ou o Chozo de Fofe. A este grupo de chozos correspóndese un dos tipos descritos por Xaquín Lorenzo, «chouzos isolados feitos aproveitando refuxios naturais proporcionados polos penedos e que se compretan con pedras miúdas» (Lorenzo 1959: 3).

Por norma xeral, estes chozos están localizados nas cabeceiras de vales abertos rodeados por pequenas dorsais que acoutan unha ampla zona de val onde se localizaría a zona de pasto e pola que discorre sempre unha corrente de auga. A súa construción realízase a partir do aproveitamento de varios bolos graníticos. Podemos ver que non sería descabelado pensar que, orixinariamente, estes espacios funcionasen coma abrigos naturais ós que, co paso do tempo, se lle foron engadindo elementos artificiais mellorando tanto o habitáculo coma o seu entorno inmediato, coa construción de currais, cortellos, etc.

\begin{abstract}
Abrigos artificiais
Refuxios realizados enteiramente en pedra, xeralmente dispersos e illados seguindo diferentes solucións, unhas máis simples e outras máis elaboradas. De tódolos xeitos, para a construción destes refuxios sempre aproveitan algún afloramento para fixar unha ou varias das paredes, polo que non están ó $100 \%$ illados ${ }^{5}$. A súa planta é variable distinguindo entre:

\section{Chozos de planta redondeada ou ovalada}

Neste caso trátase dunha única estancia á que se accede por unha porta antecedida por un pequeno pórtico exterior ou cerco de pedra, en forma de arco a modo de pequena entrada que podería ter a función dun vestíbulo ou corredor aberto.
\end{abstract}

\footnotetext{
${ }^{5}$ A pesar de que, nestes chozos, unha das paredes pertenza a un afloramento, os consideramos como abrigos artificiais xa que, de non haber refuxio, tampouco serían considerados abrigos naturais, senón sinxelamente afloramentos ou bolos graníticos.
} 


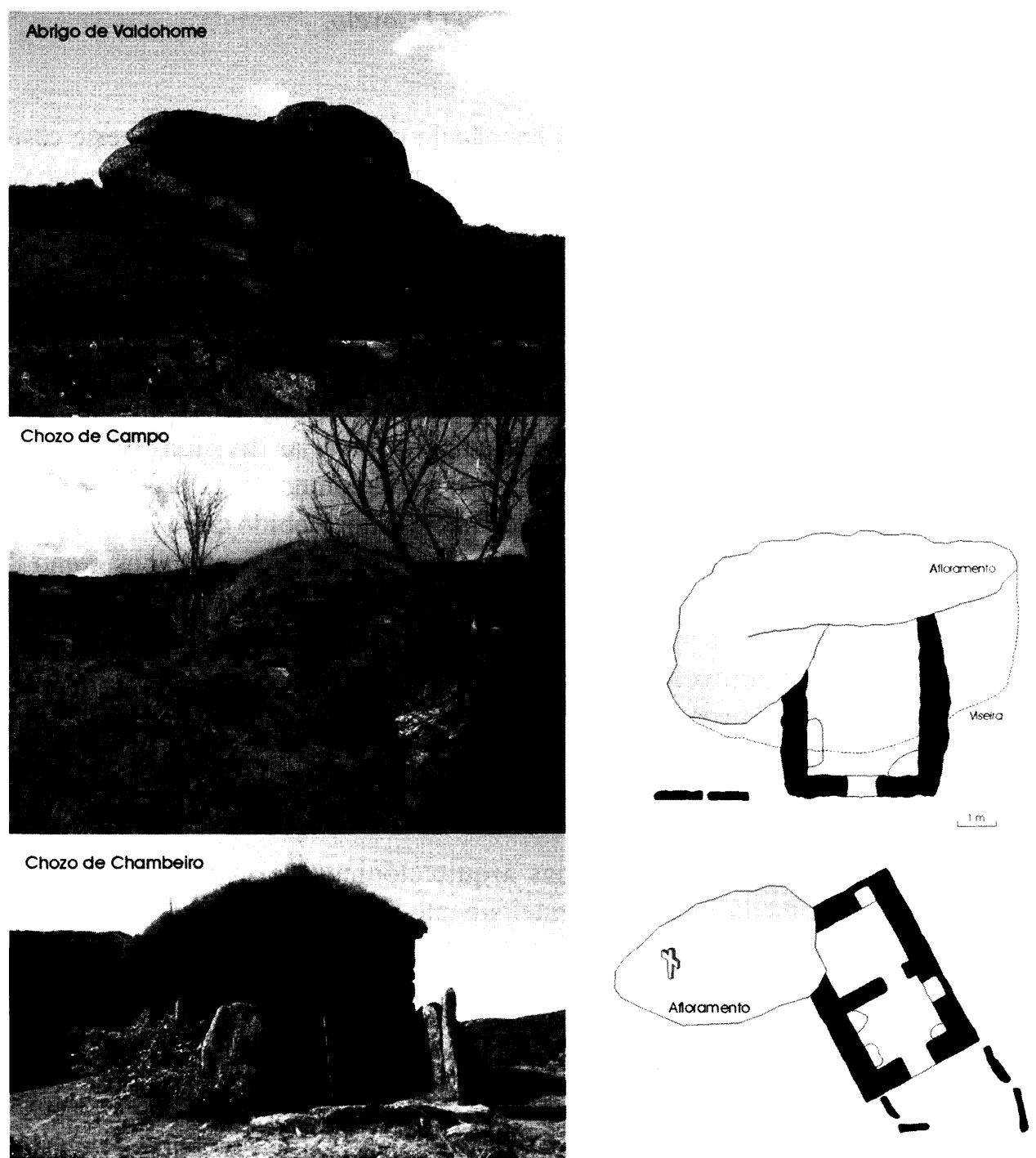

Lámina 5.- Tipoloxía constructiva dos chozos na Serra do Suído. 
Sería o caso do Chozo de Carballa de Nabal en O Covelo; e os Chozos de Forzáns I e II en Fornelos de Montes. Ás veces no propio habitáculo hai unha división interna que diferencia a zona da lareira da zona onde iría o camastro, como por exemplo o Chozo de Portela das Travesas en O Covelo.

\section{De planta cadrada ou rectangular}

Estes chozos poden ser dun único habitáculo ou de dous, dividido neste caso por medio dunha parede interna feita tamén en pedra. No primeiro caso estarían tódolos chozos localizados en Avión: Chozo de Mangüeiro, de Rodeiro, de Abelenda, etc.; no segundo caso estarían os chozos de Bidueiros, de Redondo ou o de Chambeiro en O Covelo; ou o Chozo de Silvares en Fornelos de Montes.

\section{Chozos de planta lonxitudinal}

Sería o caso dos chozos localizados no Curral de Vilán en O Covelo. Son refuxios de caracter marcadamente lonxitudinal con varias divisións internas, o que dá lugar a varias estancias, algunhas delas intercomunicadas polo interior e polo exterior, dependendo da finalidade do habitáculo. Debido tanto ó seu estado de abandono como ó exceso de vexetación que invade as construcións como ó entorno e a falta de información oral, non foi posible documentalas en maior medida, así como tampouco se puido indagar sobre o uso e función que tiña cada unha das estancias que conforman cada construción. Puidera ser que pola súa complexidade estes chozos albergarían a mais dun pastor, ou mesmo puidera ser o caso de que en época de pastoreo se trasladaran alí varias familias. En todo caso son refuxios que representan unha tipoloxía máis dentro das varias documentadas na serra.

No tocante ós diferentes sistemas arquitectónicos de peche atopámonos unicamente con cubertas realizadas enteiramente en pedra de granito. Por norma xeral, estas cubertas en pedra empréganse en determinadas categorías de edificios non propiamente de habitación. Son típicas dos fornos comunais como por exemplo os de Avión, e dos hórreos de determinadas zonas onde abunda este material. No caso dos chozos, estas cubertas rematan cunha grosa capa de terróns de herba que impermeabiliza e proporciona o illamento térmico que precisa o habitáculo, e cuxa reposición e moi sinxela xa que este material se atopa na mesma beira do chozo. As cubertas poden ser:

- De dobre vertente. Cuberta realizada a base de grandes lousas de pedra, montadas unhas sobre outras e orientadas en sentido lonxitudinal, realizada sobre os chozos de planta cadrada ou rectangular. Esta dobre vertente susténtase sobre: 
- Arcos de medio punto, encontrados unicamente nos chozos pertencentes ó concello de Avión ${ }^{6}$. Os arcos, realizados sen ningún tipo de argamasa, están reforzados por pesados contrafortes exteriores de sección cuadrangular, feitos con cachotería e levantados ata a metade da parede. Estes contrafortes sosteñen o peso e o empuxe que exercen os arcos interiores sobre os muros evitando que o arco se abra. Hai exemplos de construcións con arco que non dispoñen de contrafortes exteriores. Neste caso, o peso do arco descarga directamente sobre as paredes do chozo. E dicir, estas paredes funcionan como muro de descarga, chamadas tamén muros de dúas caras. É interesante destacar que, nas aldeas deste concello, e en cada unha delas, hai un forno comunal, e a súa construción é moi similar ou case idéntica á dos chozos na serra: construídos enteiramente en pedra $\mathrm{e}$ cuberta a dúas augas con arcos de medio punto no interior ${ }^{7}$ (Lámina 6).

- Arquitectura arquitrabada, na que se utilizan grandes linteis tanto para dividir estancias como para soportar o teito feito de grandes lousas de pedra lonxitudinais. Son os chozos de Chambeiro, de Silvares, de Redondo ou de Bidueiros.

- Cuberta en «falsa cúpula». Solución arquitectónica de cuberta en pedra, complexa e elaborada, realizada basicamente sobre edificios de planta circu-

\footnotetext{
${ }^{6}$ No concello de O Covelo, no lugar de Salcedo, tamén foi atopada unha construción adxectiva, anexa a unha vivenda e utilizada actualmente como pendello, cun arco de medio punto similar ós arcos dos chozos de Avión. Descoñecemos, polo de agora, cal foi a finalidade e destino desa construción.

${ }^{7}$ É necesario facer mención ós fornos de pan de Avión. Ó igual que os chozos, estes fornos son de propiedade comunal. Cada pobo tiña como mínimo un forno. A documentación histórica fálanos da riqueza agrícola e da importancia do pan do concello. De feito, no século XV, as parroquias de Avión eran as que pagaban máis dezmos en cereal e pan de todo o Ribeiro ó señor de Ribadavia: a parroquia de Abelenda pagaba 16 fanegas de pan de centeo e millo, a de San Cristóbal 12 fanegas, e a de San Xusto 40, dezmos que seguiron pagando ata 1837, ano no que Isabel II aboliu definitivamente o pago da «fumaza». Isto ven demostrar que, ata mediados do século XX, Avión era unha importante zona produtora de cereal ata o punto de ser considerado este concello como «o celeiro do Ribeiro». Os fornos comunais fixéronse para dar servizo a pequenas entidades poboacionais. Construíanse colectivamente polos veciños, cada un dos cales aportaba o seu traballo ou pagaba o correspondente xornal a un obreiro. Estes fornos de Avión pertencen á tipoloxía de fornos de planta cadrada ou rectangular, con cámara circular, realizados en cachotería e pedra de canteiría (utilizaban bo material co fin de que non soltase areilla nin se agretase facilmente coa calor). A cuberta é a dúas augas, realizada con lousas de pedra superpostas, polo xeral apoiadas directamente sobre arcos de medio punto, aínda que nalgúns fornos a cuberta apoia directamente sobre unha estrutura de madeira. A restauración e consolidación destes fornos estase a levar a cabo polo obradoiro de Emprego «Médelle» desde o verán de 2003.
} 


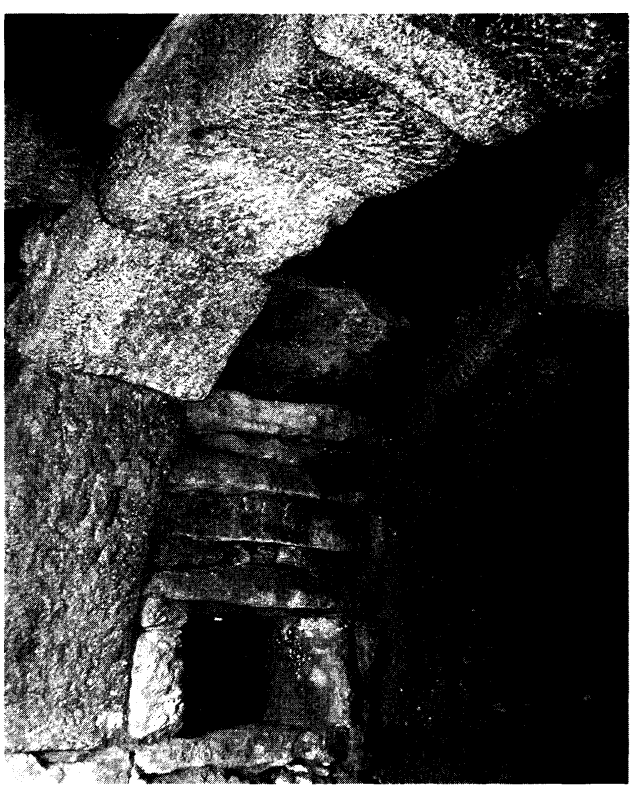

Interior do Chozo de Abelenda

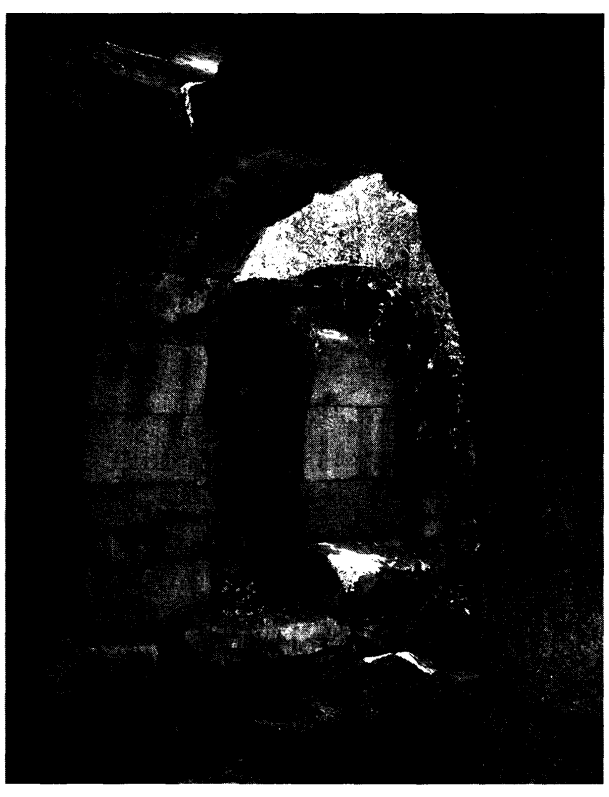

Interior do Forno de Barroso

Lámina 6.- Arcos de medio punto que sustentan as pesadas cubertas de pedra. Nesta lámina se pode observar a similitude constructiva que existe entre os chozos e os fornos comunais de Avión.

lar ou ovalada, aínda que tamén a podemos atopar en construcións de planta cuadrangular. Está feita con lousas dispostas en forma de aneis horizontais que se van sobrepoñendo cun diámetro sucesivamente máis pequeno a medida que se sube en altura, de modo que cada anel sexa un pouco menor que $o$ anel sobre o que se apoia. A abertura central vaise estreitando ata reducirse a un buraco de pequeno diámetro que se pecha por unha ou máis laxes planas pousadas sobre este último anel. Estas laxes quedan encaixadas polo seu propio formato e peso, unhas contra as outras, ata o cume que remata e consolida toda a obra (Veiga de Oliveira 1994: 145-46). As pedras colocadas están á vista no interior da cámara, sen ningún tipo de reboco. A sustentación deste tipo de cuberta pode ofrecer algúns problemas técnicos, polo que se recorre á construción dunhas paredes moi grosas para descargar do peso e dotar dun equilibrio estable a toda a construción. É o caso do Chozo de Fofe, de Piñeiro, de Campo, Portela das Travesas, Carballa de Nabal, etc.

- Ou solucións de factura máis tosca, nas que se adaptan os muros e a cubrición ós afloramentos e abrigos graníticos da zona. 
No que se refire á distribución e división interna do chozo, usualmente perto da entrada estaba a lareira, cun espacio para poñer a leña, e no fondo situábase o camastro. Os elementos normalmente presentes no interior dos chozos son:

- Cama ou camastro: No chan, co leito feito de toxo moar que, segundo contaba Emilio Gabián, informante de Avión, o gandeiro o machucaba coas súas chancas, e despois o cubría de fento, colmo ou xestas, sobre o que dispoñía as mantas. O resto do habitáculo, tamén térreo, as veces cubríano de toxo seco ou palla para mantelo seco e quente. Normalmente o camastro sitúase no fondo do chozo.

- Lareira, sobre o chan de terra ou sobre unha lousa, onde se quentaba a comida e se mantiña quente o habitáculo. Soe estar localizada á beira da porta xa que estas construcións non teñen cheminea, saíndo o fume pola porta ou por algún oco ou ventanuco feito na parede a modo de tiro. Nestas construcións, ó carecer de cheminea, o fume invade toda a estancia. Este fume, entre outras cousas, ten a propiedade de conservar as provisións e, sobre todo, é un método tradicional que permite sanear o habitáculo de parásitos e demais insectos.

- Alacea: Poden ter unha ou varias e están emprazadas nas grosas paredes, onde gardaban a comida, roupa, ferramentas e aparellos dos animais e outro tipo de travellos.

Case todas as construcións teñen unha ou dúas bufardas ou pequenas xanelas verticais, orientadas cara o nacente e o solpor, que ademais de ventilar o habitáculo facilitando as correntes naturais, iluminaban e servían para vixiar o gando, xa que desde elas contrólase a zona de pasto.

Os chozos só teñen unha entrada. Esta porta ten un lintel de grandes dimensións sustentado por dúas laxes a modo de portais. Nalgúns casos este acceso é de pequeno tamaño para evitar que os animais accedan ó interior do habitáculo ou para illar ó máximo posible esta construción das inclemencias do tempo. Esta entrada pechábase cunha porta de madeira. Curiosamente, en ningún dos chozos localizados atopamos restos de portas, aínda que ás veces si atopamos marcas ou sinais de peche nos portais da entrada. Xaquín Lorenzo, ó describir as cabanas de pastores no Leboreiro, di que nas pedras que forman as portas non había sinais de bisagras. El inclínase a pensar que o acceso tapábase con táboas unidas entre si e que se porían no oco da entrada para evitar o frío e o vento, tal e como no seu tempo se facía nas habitacións de verán no pobo portugués de Castro Leboreiro (Lorenzo 1947: 349). Pola enquisa etnográfica realizada soubemos que as portas dos chozos sacábanse cando acababa a tempada de verán. Deste xeito, evitábase que alguén as destragara ó querer entrar, e ó mesmo tempo o chozo, ó quedar aberto, servía como refuxio dalgún animal ou persoa no inverno. Severino Fernández, informante do lugar de Mouriscados, concello 
de Avión, describiunos o sistema de enganche da porta, realizado por medio dun eixo rotatorio, un «touzo» ou «touro» de madeira, encaixado por medio de dúas cazolas gravadas na pedra, unha enriba e outra embaixo. Severino contábao así:

«...abaixo ten unha pociña feita nun canzorro de pedra e súbese para un burato, desta maneira anda ó redor, abre e cerra».

Outro elemento característico destes refuxios é a existencia dunha ou varias pías labradas nun afloramento a carón do chozo ou nas súas inmediacións, e que reciben o nome de «cazoliñas». Segundo a enquisa, puidemos saber que estas cazolas gravadas na pedra, de base plana, eran realizadas polo pastor para servir nelas a súa comida ou tamén a dos cans. Preguntando ós informantes se sabían que facían os ghandeiros no seu tempo libre, Brasilio Fernández, informante do lugar de Airoa, Fornelos de Montes, contounos que cando estaban os chozos en uso, os pastores subían a eles cun cicel e cun martelo e, nas rochas, facían cazoliñas nas que despois botaban a comida que quentaran anteriormente na lareira, ou mesmo «... botaban o leite, recén muxido, con pan».

\section{Cortellos}

Trátase de pequenas cuadras de propiedade particular, localizadas en torno ós chozos, destinadas a resgardar ós becerros, que, a diferencia dos chozos, son de propiedade particular.

A súa construción é moi semellante á dos chozos, mesmo con alaceas interiores e con ventanucos, reproducindo, ás veces, o seu esquema constructivo. O chan está escavado por debaixo do nivel da superficie exterior, co obxectivo de deixar lugar para unha capa de toxo e distintos tipos de malezas naturais procedentes do monte, que serven como cama ós animais, que ás veces é cuberta cunha capa de palla para que os toxos non danen á cría do gando. O caso máis destacado é o dos cortellos dos chozos de Avión, concretamente os cortellos do Chozo de Mangüeiro, e os de Rodeiro. Son reproducións case exactas dos chozos pero sen arcos interiores e de dimensións menores, as xustas para albergar unha cría ou dúas. Construídos enteiramente en pedra, con teito a dúas augas tamén de pedra e recuberto de terróns (Lámina 7).

Nalgunhas zonas do Suído estes cortellos reciben o nome de «parideiras» nome que deriva do uso que se lle dá a estas pequenas construcións destinadas unicamente ó resgado das crías recen «paridas». Tamén podemos atopar agrupacións de varios cortellos sen ningún chozo asociado. Un exemplo son as «Parideiras de Casariños» en Airoa, Fornelos de Montes.

Cuadernos de Estudios Gallegos, Tomo LI, Fascículo 117, Santiago 2004. (Págs. 9 - 48) 


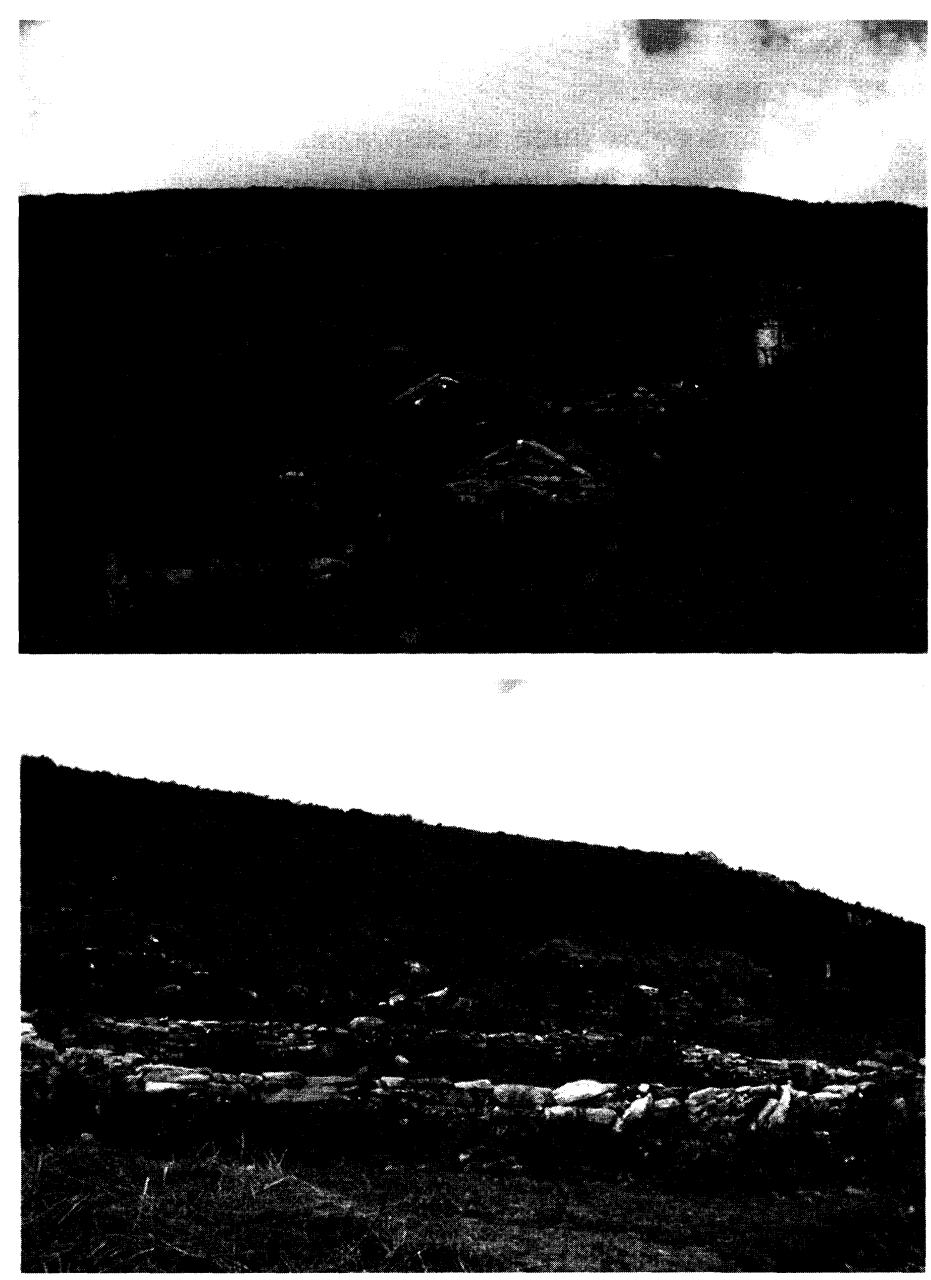

Lámina 7.- Na imaxe superior, vista xeral do Chozo de Rodeiro cos seus respectivos cortellos, neles se reproduce o mesmo esquema construtivo que na habitación do pastor. Na imaxe inferior, o Chozo de Abelenda co seu curro en primeiro termo.

Un caso curioso e peculiar foi o dun cortello localizado no Curral de Campolongo, en Fornelos de Montes. Trátase dun curral unitario realizado enteiramente en pedra, no que varios cortellos se dispoñen en torno a un valo circular de pedras. Pese ó seu mal estado de conservación se puido observar que cada un dos cortellos, de planta circular, tiña dúas portas, unha para acceder ó propio cortello desde fóra e unha segunda para acceder ó curral. Dispoñen de 
ventanucos, e as súas cubertas, a pesar de que non se conservan en ningún, o mais probable e que fosen de pedra.

No alto da serra, nos cotos onde se emprazan os sesteiros ou as chairas, atopámonos cunha construción que igualmente denominamos cortellos; aínda que a súa forma e destino é distinto, xa que son construcións moito máis sinxelas que serven de abrigo do pastor contra o vento e o sol. Están constituídos a base de muros de pedras de granito, de diferentes tamaños, encaixadas unhas sobre outras, aproveitando algún penedo ou afloramento para formar o peche, e levantados contra a dirección do vento dominante, tendo forma, nalgúns casos, de pequena torre ou murete contra a cal as persoas déitanse. Descoñecemos o seu uso, se é unicamente para as persoas ou se nestes pequenos abrigos artificiais tamén se regardaba algún gando, aínda que polo seu tamaño inclinámonos a pensar que só era para as persoas, lugares que mesmamente poderían seguir sendo usados polos cazadores ${ }^{8}$.

\section{Os curros}

Son peches de pedra utilizados para gardar o gando durante a noite. Podémolos atopar ben unidos ás cabanas ou ben situados nas proximidades, polo xeral nos prados (Lámina 7).

Son recintos de planta variable, polo regular de forma cadrada ou circular, e levantados polos veciños como un traballo comunal máis, pechado con muros a base de cachote, laxas ou bloque de pedra de granito ou gneis, cunha serie de aberturas ou portas de acceso que permiten o paso do gando. Algúns destes curros teñen adosados un ou varios cortellos para o resgardo das crias.

\section{Os sesteiros}

Os sesteiros son aqueles lugares onde repousa o gando, nas zonas altas e frescas da serra, nos cotos. Normalmente estes espacios están acoutados no seu perímetro por un valo no que se integran os abundantes afloramentos graníticos. Cada chozo tiña o seu sesteiro demarcando, deste xeito, a súa propia área de pastoreo. Así ocorre co Sesteiro de Cernadas, de Mouro, de Rodeiro, de Bidueiros, do Curral do Corno entre outros (Lámina 8).

O valo, na maior parte das veces, é unha parede de pedra entre un metro e metro e medio de altura, constituído co material existente no lugar do seu emprazamento.

\footnotetext{
${ }^{8}$ No NE portugués, na Serra Amarela, Tras-Os-Montes, na Serra da Estrela, ou no Alentejo hai documentadas construcións similares denominadas malhões. Trátase de construcións moi simples, definidas como abrigos contra o vento e o sol e constan duns grosos muros de pedra seca encaixados sen cuberta algunha, levantados contra a dirección do vento dominante (Veiga de Oliveira 1994: 27).
} 

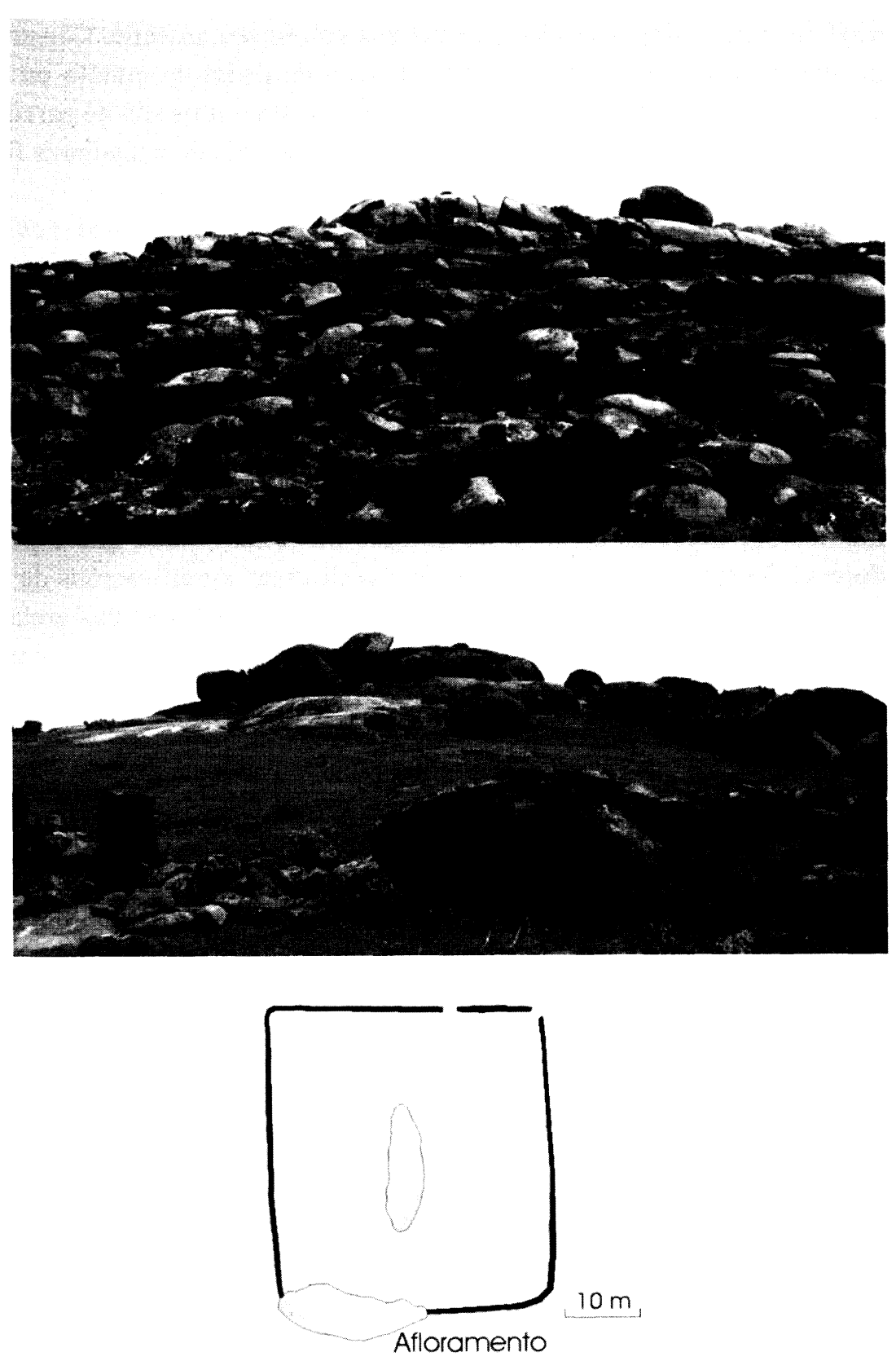

Lámina 8.- Emplazamiento e detalle do peche do Sesteiro de Chambeiro. De planta rectangular e dúas entradas, unha polo $\mathrm{N}$, e outra polo NE. O seu valo está formado por laxes e cahotes de granito, integrando na súa estructura varios dos afloramentos que hai no cume. 
Hai varios tipos definidos segundo as características do seu aparello. Construídos por superposición de cachotería racheada en seco de pedra de granito ou gneis xunto con chantos espetados no chan. Outras veces estes muros son de paredes de cantería, de dobre paramento con recheo interno de cachote en irregulares fiadas, como é o caso do Sesteiro de Bidoas.

Outro tipo de espacio para o pastoreo definido na serra son as chamadas chairas. Estes lugares están localizados nas planicies elevadas onde pastaba o gando na época estival. Esta área de pastoreo, ó contrario dos sesteiros que están pechados por un valado no seu perímetro, pode estar parcialmente delimitada por medio de sinais que poden ser aliñacións de lousas, pedras pintadas, ou ben afloramentos naturais destacados na paisaxe.

Por último, en toda a serra atopámonos con outeiros pedregosos acondicionados co obxecto de mellorar as labores de apacentamento do gando, xa que entre os afloramentos hai espacios a modo de abrigos ou refuxios nos que é posible resgardecerse. Veñen a ser paraxes naturais con diversas modificacións de orixe antrópico, nas que se rexistran acumulacións de pedras nas bocas das gretas das entradas ós abrigos ou nos orificios das rampas ou pasadizos de acceso ós peñascos. Estas acumulacións de pedras a modo de muretes tiveron e seguen a ter o obxecto de evitar que os animais se introduzan naqueles lugares dos que despois sería difícil facelos saír, así como tamén teñen a función de impedir que os animais poidan subir ó alto dos peñascos co evidente peligro de despeñe.

\section{Os foxos de lobo}

Outras construcións relacionadas co sistema de explotación gandeiro da serra son os foxos de lobo, recintos destinado á captura do lobo mediante batidas comunais. A ameaza que supoñía a existencia de lobos nestas zonas de explotación gandeira e pastoril motivou a estas comunidades a construir unha serie de estruturas para dar caza e morte a estes animais depredadores.

As referencias escritas máis antigas de foxos aparecen no ano 994, nunha acta feita en Coimbra: «uindo hereditaten meam propiam que habui de parte de mea muliere guda in uilla manualdi quomodo se leua de petras ueiras et de inde in fogo lopare et dividet cum pasada». Ou no ano de 1114, cando no canon XV do Concilio de Santiago de 1114 ordenábase esa práctica: «Todos los sábados, excepto en Pascuas y Pentecostés, los sacerdotes, soltados, aldeanos, etc., se dediquen a la caza de alimañas mediante la persecución hasta las hoyas». Posteriormente foi reseñada a súa presencia en numerosos documentos e escritos.

Segundo a súa tipoloxía e modo de utilización existen cinco tipos distintos de foxos: o foxo simple, o foxo de cabrita, o foxo de paredes converxentes, o foxo de

Cuadernos de Estudios Gallegos, Tomo LI, Fascículo 117, Santiago 2004. (Págs. 9 - 48) 
trampa e o curral. A tipoloxía dos foxos documentados nesta zona, o Foxo do lobo de Portela das Travesas, no concello de O Covelo e o Foxo de Pigarzos, en A Lama, pertence ó chamado «foxo de paredes converxentes», que segundo as rexións da Península recibe diferentes denominacións (chorco, callejón, lobera, hoyos, canes, caleyos, hoyas, callejos...), podéndose prescindir dos elementos arquitectónicos básicos segundo sexan as condicións topográficas. $\mathrm{O}$ foxo de paredes converxentes redúcese construtivamente a dous muros de cachotería en forma de $\mathrm{V}$ de ata un kilómetro de lonxitude e dous ou tres metros de altura, denominados sebes, quizais en función da súa primitiva construción a maneira de paramento de estacas ou arbustos, en cuxo vértice se sitúa un recinto de planta circular ou cadrada de tres ou catro metros de lado. Este recinto está escavado a xeito dun pozo, duns dous ou tres metros de profundidade, e protexido por muros de iguais características aos xa mencionados, tendo o seu acceso por un pequeno oco situado no vértice da uve (Llano 1983: 387).

O seu emprego asóciase sempre a unha batida comunal, efectuada por un elevado número de persoas nunha data específica, co obxecto de conducilo a un lugar determinado onde existía unha cavidade ou trampa, acabando por caer no foxo que fora previamente cuberto de vexetación. Esta cacería está hoxe en día desaparecida e con ela os últimos restos deste tipo de construcións. Unicamente quédanos como recordo de esa cacería a toponimia como por exemplo o Foxo do lobo (o antigo «fogium lupolem»), O Foxo, O Curro, etc.

Outro tipo de trampa feita para a caza do lobo, pero neste caso máis sinxela e igual de efectiva é a que Brasilio de Airoa narraba na enquisa que lle fixemos. El recordaba como os seus avós, "os antigos», facían outro tipo de trampas para atrapar ó lobo, textualmente contábao así:

"Ali onde se cruzaban varios camiños transitados polo lobo, escavaban un buraco de tres por tres ou catro por catro. Era un burato [...] pero fondo de oito ou dez metros, metian un ghran pao no medio de carballo e poñian un caixón de madeira [...]. No caixón poñian unha ouvella ou unha cabra viva [...] poñian un pao cruzado e botábanlle leña e toxo por riba, o lobo ouia a ovella e ó querer ir a por ela [...] caía no buraco onde se lle daba morte con paos e ghalleiras». Era o que lle chamaba "facer a cova».

\section{APROXIMACIÓN A UNHA CRONOLOXÍA INDEFINIDA}

Non dispoñemos de datos arqueolóxicos nin, polo de agora, dun estudo da documentación escrita que permita coñecer unha data aproximada para a realización

Cuadernos de Estudios Gallegos, Tomo LI, Fascículo 117, Santiago 2004. (Págs. 9 - 48) 
destas construcións. O que faremos a continuación e expoñer unha serie de hipóteses recollidas de algúns dos autores que escribiron sobre os chozos do concello de Avión, e hipóteses produto das nosas incipientes pesquisas.

A Idade Media é o momento do que se parte para indicar o inicio da explotación gandeira extensiva nas serras, o que conlevaría a realización de determinadas construcións para o seu desenvolvemento. Xaquín Lorenzo, na consulta da documentación que fixo para os seus estudos da Serra do Leboreiro recolle que «No $s$. XII, nos tempos de Alfonso VII, os documentos fálanos de que esta serra era aproveitada polos gandos do Mosteiro de Celanova, onde os seus pigureiros fundaron poboados, como A Fraga, Parada, A Ramallosa, Porcarizas e outros» (Lorenzo 1959:1).

Os chozos de Avión, polo tipo de construción que presentan e, basicamente, polos arcos de medio punto que foron utilizados como solución sustentante da cuberta, viñeron datándose tradicionalmente entre os séculos XII-XIII, pola súa semellanza coas primeiras igrexas de estilo románico. Bejarano Galdino (1986: 30-33) basándose en datos históricos, concretamente no estudo das roturacións levadas a cabo nos séculos XI-XIII, no val do Baixo Miño', considera a Baixa Idade Media como posible data de construción destes chozos de Avión, nun momento en que ademais a arte Románica estaba en pleno auxe. $\mathrm{O}$ autor recolle que en Pena Corneira, no macizo da serra do Faro, hai unha pequena igrexa románica, Santa María de Lamas, do s. XI-XII, o que nos dá unha referencia de que o estilo románico xa era coñecido na zona por aquel entonces.

Porén, este tipo de arquitectura tivo un tempo de pervivencia moito máis amplo, polo que non podemos descartar unha data de construción máis tardía, retraéndose ós séculos XVII-XVIII, época na que ademais a explotación campesiña e gandeira estaba en pleno auxe. Eladio Rodríguez (1996) cita a existencia dun documento pertencente a un testamento de 1792, do escríbano D. Xosé Chao, falando das estremas entre Avión, Caldevergazo ${ }^{10}$ e Soutomaior, onde se nomean os chozos que están entre eses termos.

Seguindo cos chozos de Avión queremos resaltar a similitude que existe entre estes e os fornos comunais do mesmo concello, e entre estes últimos e os fornos

\footnotetext{
${ }^{9}$ As roturacións efectuadas nesta época, nas áreas de montaña, fan que o espacio que se dedicaba a monte, onde se desenvolvía a economía gandeira, pase a dedicarse á agricultura. Iso supuxo que a actividade de pastoreo libre pasase a desenvolverse nas zonas mais altas e a ocupar terreos na serra (Menéndez 1999: 10).

${ }^{10}$ Ata 1841 o municipio denominouse Caldevergazo, e foi a partir dese ano cando tomou o nome da súa parroquia máis importante: A Lama (Caeiro 1993: 616).
} 
rexistrados na comarca da Limia e Baixa Limia, así como os da zona portuguesa de Peneda-Gerês. Xaquín Lorenzo, coñecedor destes lugares, ilustrou o exterior dun forno comunal situado en Asperelo, Entrimo, documentado como un dos máis antigos da Baixa Limia. Tratábase dun forno comunal realizado en pedra, con cuberta asentada sobre arcos interiores; de feito, no debuxo obsérvase, no lateral da construción, un pesado contraforte que nos está a indicar o arco de medio punto interior. Seguindo na procura de máis fornos deste tipo localizamos un en Tourén, localidade pertencente á Serra do Gerês, chamado o Forno do Povo. Trátase dun edificio enteiramente en pedra. A fachada principal está sustentada por tres pesados e grosos contrafortes sobre os que descargan os arcos que internamente sustentan a pesada cuberta de pedra.

Esta gran similitude constructiva entre os fornos comunais tanto de Avión como da zona sur de Ourense e maila área portuguesa, pódenos estar a indicar que a construción destes chozos pode ter certa relación coa construción dos fornos. A documentación antiga, mencionada por outros autores, remítenos ó s. XV cando as parroquias de Avión eran as que pagaban ó señor de Ribadavia, máis dezmos en cereal e pan de todo o Ribeiro, xa que Avión era unha importante zona produtora de cereal ata o punto de ser considerado como «o celeiro do Ribeiro». Por outra banda a incorporación do millo na economía galega dá lugar a un xiro na transformación do terrazgo dando lugar a unha serie de cambios no que se refire ás rotacións, abonado e, sobre todo, no incremento do traballo, e na dieta alimenticia (Ballesteros 2003: 28). As primeiras noticias que se teñen do seu cultivo datan de 1609-20, e na Rías Baixas hai que chegar a 1628-30 para ver os campesiños sementar e consumir o cereal de forma masiva (Saavedra 1992) converténdose en pouco tempo no cereal mais abundante. Esto fainos pensar que os construtores dos chozos de Avión puideron tomar como modelo o edificio do forno, podendo ser contemporáneos ou algo posteriores ós fornos, abrindo un abano posible entre o século XV e XVII. Con esta hipótese que acabamos de formular non descartamos a posibilidade de que estes chozos poidan ser mais antigos, podéndose construir sobre outros anteriores e que, debido quizais a determinadas necesidades, como por exemplo a ampliación da cabana gandeira, etc., decidisen as comunidades levantar outros novos «seguindo o modelo dos fornos». Pero esto son só hipóteses que esperamos chegar a concretar con posteriores investigacións.

Cousa distinta son do resto os chozos da Serra do Suído, os de O Covelo e Fornelos, que non teñen nada que ver cos anteriores. Ó analizar o conxunto deles puidemos chegar a unha análise preliminar dos diferentes tipos construtivos que se dan na serra. Estas diferencias poden ir dacordo co momento de construción, e que a división proposta anteriormente de abrigos naturais, semi-naturais e artificiais 
veña a corresponderse con distintas e diferentes épocas de realización destes refuxios. Esto non tería que ver cos momentos de ocupación destes espacios, pois, como xa apuntamos en apartados anteriores, a ocupación e uso das zonas de pasto pode retraernos a épocas moi antigas que co tempo fóronse modificando e axeitando segundo as necesidades de cada momento.

Finalmente, do que si dispoñemos, por enquisa etnográfica, é de datos reais sobre o momento de abandono das diferentes agrupacións de chozos. Parece ser que os primeiros en abandonarse foron os da zona de Fornelos de Montes, os chozos do Curral de Forzáns e os de Campolongo. De feito, Brasilio, de 81 anos, xa non os viu en uso. Tamén sabemos que os últimos foron os de Avión, haberá uns 40 ou 50 anos.

\section{A RIQUEZA PATRIMONIAL DO SUÍDO}

Desde o punto de vista histórico chegamos a coñecer, pola consulta de documentación e, sobre todo, pola información obtida a través das enquisas etnográficas, como se desenvolvía a actividade gandeira na serra, ou como se organizaban as comunidades dos diferentes pobos próximos á serra.

Para desenvolver esa actividade creouse unha infraestrutura necesaria para organizar o pastoreo. Tras unha aparente simplicidade encontrámonos cunhas construcións esencialmente funcionais nas que foi necesario tanto un coñecemento exhaustivo do medio para a súa ubicación e como coñecementos técnicos para levar a cabo unha transformación e manexo de distintos tipos de pedra, arxila e terra para o seu levantamanto. Descoñecemos cando se realizaron, como se realizaron, quen as realizou ${ }^{11}$ aínda que co tempo esperamos chegar a ingadar nestas cuestións. Polo de agora, e tras a exposición das diferentes construcións atopadas na serra temos que no conxunto da Serra do Suído, podemos establecer diferencias tipolóxicas tanto a nivel da construción como a nivel organizativo, dependendo dos diferentes lugares poboacionais. Deste xeito, hai catro grandes conxuntos que se corresponden cos catro concellos que converxen na serra: Avión en Ourense, A Lama, Fornelos de Montes e O Covelo en Pontevedra.

\footnotetext{
${ }^{11}$ Posiblemente puideron ser feitos por artesáns da pedra, como os pedreiros que extraen e preparan as pedras nas canteiras do monte ou os chamados picapedreiros que as preparan no lugar de colocación dos edificios. Os canteiros e picapedreiros aínda que estes dous oficios estiveron presentes en case tódalas comarcas de Galicia, parece que a zona que foron especialmente numerosos na zona máis comprendida polas comarcas montesías de Pontevedra e os arredores da capital coma Terra de Montes, Cotobade, Cuntis, A Lama.
} 
Un dos casos máis paradigmáticos, e dos que temos mais información tanto a nivel documental coma etnográfico, é o do concello de Avión. Os pobos de Avión emprázanse na ladeira orientada cara o leste da serra e no fondo do val por onde discorre o Río Avia. Cada un destes pobos, de economía, no pasado, predominantemente gandeira, tiña o seu chozo ${ }^{12}$. Os seus chozos tamén teñen unhas características que difiren bastante dos localizados noutras zonas da serra, e se resumen fundamentalmente en: existencia de arcos de medio punto no seu interior, contrafortes exteriores, teito de pedra a dúas augas e planta rectangular.

A zona de A Lama é a única onde non atopamos chozos. Pola contra, é nesta zona da serra onde se atopan os sesteiros utilizados polos pastores de Avión ou Fornelos. É tamén nesta zona da serra onde se atopa un foxo de lobo (o outro está no concello de O Covelo), e onde está o único curro de bestas, onde levaban a marcar os cabalos da serra. Posiblemente o feito de que non haxa chozos se deba ás condicións topográficas deste lado da serra, orientada cara o poñente, moito menos agreste, con moito mellor acceso e amplas zonas de pasto por ser máis chan e cuxas entidades poboacionais, Pigarzos ou Xesta, aínda que están aproximadamente á mesma altitude que o resto dos pobos da serra, están moito mais próximas a ela, compartindo espacios de cultivo e de pasto. O máis posible é que esta inexistencia de construcións para albergar ó gando se deba a que ó ser o acceso mais doado e estar máis próximo ó núcleo habitacional, os mesmos donos poden ter conta das reses sen que iso signifique moita inversión de tempo nin unha dedicación específica. Posiblemente é por iso que non fai falla que a comunidade se dote dunhas infraestruturas para manter esa economía gandeira.

No concello de O Covelo, os pobos están a certa distancia da serra e o seu acceso non é moi doado, pois hai que salvar unha acusada pendente para chegar á zona de pastos. Nesta zona rexistráronse nove chozos, dos cales tres son de planta rectangular e teito a dobre vertente nos que se utiliza a solución alintelada para sustentar a cuberta de pedra a dúas augas. Os restantes son chozos que se poden definir como abrigos seminaturais, de planta que tende a forma circular ou ovalada e con cuberta de pedra en falsa cúpula, todos cun emprazamento moi peculiar, a media ladeira, cun gran dominio visual sobre un amplo val polo que discorre un rego.

${ }^{12}$ Puidemos saber da existencia de doce chozos en Avión, aínda que do de Boeixas, Beresmo e un segundo chozo en Abelenda, só se supón a súa ubicación, xa que están totalmente desaparecidos, sendo moi posible que estean enterrados no propio lugar; dos restantes, tres están semiderruídos: Mouriscados, Amiudal, e Carixa; e os sete restantes reconstruídos e recuperados polo Obradoiro de Emprego «Os chozos». 
Finalmente a zona de Fornelos de Montes difire un pouco do resto. Atopámonos cunha serie de construcións entre as que hai chozos, currais e cortellos, e todo este conxunto recibe o nome de curral. Estes currais caracterizábanse por ser construcións múltiples de distinta índole, tamaño, tipoloxía, todos distribuídos nun amplo val por onde sempre discorre unha corrente de auga. Son os peor conservados dos localizados na serra e, polo que puidemos indagar, parece que foron os primeiro en abandonarse.

Neste tempo, tamén se documentaron varios sesteiros, valos, xa sexan das $c a-$ vadas ou de calquera outro límite de propiedades. De tódolos xeitos, pensamos que a documentación destes valos, máis abundantes no concello de Avión e A Lama, é unha tarefa pendente porque é a única maneira de indagar sobre a organización e compartimentación do espacio da serra e a súa dedicación gandeira e agrícola ${ }^{13}$.

Outro tipo de construción non rexistrada na serra pero que sabemos da súa existencia, tanto pola toponimia como pola enquisa etnográfica é a existencia, polo menos, dunha neveira ${ }^{14}$, na zona $\mathrm{N}$ da serra do Suído xa que os topónimos de Neveira ou de Navenlla, O Pozo ou Pozo Novo, eran bastante significativos. Este indicio o puidemos constatar gracias ás referencias de xente nova que coñecía a serra. Algo curioso foi que os informantes de máis idade enquisados descoñecían a súa existencia nin tampouco oíranlles falar delas ós seus pais. A existencia deste tipo de construción relacionada co abastecemento de neve viría a completar toda unha tipoloxía de construcións relacionadas cun espacio de serra e coas

\footnotetext{
${ }^{13}$ A través da enquisa realizada puidemos saber que a serra era o lugar idóneo para o cultivo do centeo sobre todo, e de trigo, aínda que este último cultivábase en maior cantidade no val. Este feito o puidemos constatar na serra, a través da existencia de grandes parcelas, pechadas con muros de cachote e que acoutaban superficies amplas. Estas parcelas, segundo os informantes, reciben o nome de cavadas.

${ }^{14}$ Construcións de variada tipoloxía dedicadas exclusivamente ó almacenamento e conservación do xeo para a súa posterior distribución e venta. Poden ser naturais ou artificiais. As primeiras consisten no aproveitamento dalgunha cova ou de dolinas situadas nas ladeiras orientadas cara o norte das serras, onde se acumulaba a neve e conservábase bastante tempo de forma natural. $\mathrm{E}$ as artificiais son construcións mais elaboradas que constan de dúas partes ben diferenciadas: o pozo, oquedade escavada nun declive terroso revestido, nalgúns casos, por muros de pedra de granito. Dispoñían como requisito indispensable dun fondo permeable ou, no seu defecto, dun solo levemente inclinado cara un desaugue para o escorrido da auga derretida do xeo almacenado. Poden ser de planta circular, ovalada ou cadrada, cun diámetro que pode oscilar entre os tres e os dez metros e unha profundidade entre os tres e os doce metros aproximadamente. Das cubertas de forma variada son escasos os exemplares que as conservan, sendo de forma tumular por medio dunha «falsa cupula» ou a dúas augas (Calvo 2001: 171-72).
} 
diversas actividades económicas que neste territorio de montaña se puideron desenvolver. En Galicia a propiedade ou a titularidade das neveiras hai que relacionala co Císter, sendo os séculos XVI e, sobre todo o s. XVII e XVIII a época dourada destas construcións e do comercio da neve. Gran parte das neveiras pertencían a diversos mosteiros e a posible existencia dunha neveira na Serra do Suído vinculada posiblemente a algún mosteiro, non sería de estrañar, de feito na serra situada cara o SE do Suído, a Serra do Faro de Avión, rexistráronse dúas, propiedade do mosteiro de Melón, unha en Tourón e outra en Vilar de Condes. O mosteiro da Franqueira posuía dúas neveiras e unha poza de neve. O mosteiro de Celanova tamén tivo unha; o mosteiro de San Martiño Pinario tiña unha en Silleda, en Sta. María de Xestoso; a abadía de San Clodio a tiña en Ribas de Sil; Montederramo na serra de San Mamede; tamén tiveron neveiras Acibeiro, Sobrado, Oseira, etc.

En definitiva, o conservarse ata hai pouco máis de medio século esta organización comunal na Serra do Suído é un feito a destacar e a considerar xa que nos pode estar indicando un proceso histórico da zona desde épocas moi precedentes. O máis posible é que esas zonas de pastoreo, que cumpren unhas determinadas características xeomorfolóxicas que favorecen esta dedicación, puideron ser reutilizadas a través do tempo mantendo ese mesmo espacio aínda que adaptando as construcións a posteriores melloras. Complementariamente, consideramos que para chegar a un coñecemento do espacio e á reconstrución da actividade desenvolvida nel, é necesario facer unha consulta da documentación antiga existente. Tamén consideramos indispensable que, para chegar a coñecer en profundidade este territorio, se bote man da metodoloxía arqueolóxica, aplicada nos propios chozos ou mesmo en determinadas áreas de actividade. Só así poderemos chegar a facer unha valoración máis exacta das evidencias que aínda conserva esta serra, períodos de ocupación, construcións, ou fases constructivas.

\section{RECAPITULACIÓN}

Despois desta breve exposición sobre a Serra do Suído, o seu contido e significación que de ela fixeron os pobos colindantes, debemos resaltar que este sigue sendo un territorio que desde épocas moi antigas foi utilizado como vía de transito, lugar cerimonial e de enterramentos como o atestiguan a grande cantidade de túmulos megalíticos e asentamentos estacionais relacionados, sobre todo, co desenvolvemento dunha economía que permitiu a pervivencia das comunidades asentadas nas zonas de val. 
Resaltamos que a habitación do pastor, o chozo, non se constitúe unicamente polos seu límites e forma física, senón que existe unha extensión do espacio cara os lugares onde se vive, e onde se interacciona comunitariamente, dando lugar a creación dun entorno social e cultural determinado. Así, lonxe da idea de ver este territorio como un espacio natural, a prospección realizada permitiunos captar outra concepción ben distinta, como pode ser a propia dinámica que proporcionaba este espacio e o uso «intensivo - selectivo» de determinadas zonas por parte dos seus habitantes.

Ó tempo, todas as construcións rexistradas xa fosen chozos, sesteiros, foxos, valos, cruces, camiños, etc., independentemente da época constructiva, foron realizadas aproveitando os espacios naturais máis propicios para poder albergalos, cunha adaptación ó medio tal que se creou un perfecto mimetismo entre o espacio natural, a serra, e o elemento artificial, a arquitectura. Neste sentido, destacaríamos a necesidade de ver a construción tradicional anónima como unha parte importante dentro do mundo da arquitectura.

Ó fío desto, Pedro de Llano, nunha entrevista feita no 2003, falaba de que aínda que unha arquitectura estea construída cun material ou con outro non implica que esa arquitectura teña un maior ou menos valor. O que lle dá valor é o entendemento do espacio e o uso intelixente dos materiais. É unha arquitectura perfectamente integrada no lugar, que resolvía as inclemencias da climatoloxía dun xeito sumamente efectivo. Tratábase dunha arquitectura estrictamente funcional, para vivir, traballar e gardalo gando. Arquitectura anónima, vernácula, un exemplo de racionalidade (Armesto 2003: 8). Así mesmo, temos que entender que a habitación do pastor, o chozo, non se constitúe unicamente polos seu límites físicos senón que existe unha extensión do espacio cara ós lugares onde se interaciona comunitariamente, dando lugar á creación dun entorno social e cultural determinado. Deste xeito, a perda e o esquecemento do que nos queda na Serra do Suído levaría a desaparición dun espacio histórico e cultural de significativa importancia, o mundo do pastoreo pouco coñecido no ámbito galego, as relacións comunais, de vital importancia no desenvolvemento da sociedade, a interatuación co medio natural, e múltiples aspectos máis que conforman un amplo intervalo de tempo esencial para o coñecemento da nosa cultura, e o que acabamos de expoñer so é un pequeno aporte do que realmente contén este territorio da Serra do Suído...

\section{AGRADECEMENTOS}

Ós meus compañeiros do Laboratorio de Arqueoloxía da Paisaxe, a Suso, a David, a Anxo, e en especial a Felipe Criado polo teu apoio incondicional e a todos vós 
que facedes o día a día máis que agradable. Especial agradecemento para as miñas compañeiras de traballo de campo, Sofia Veva e Tere, xuntas compartimos máis que momentos inesquecibles na serra. A Emilio Gabián, Severino Fernández, Brasilio Fernández, Eladio Fernández (e non son familia), Manolo, expresidente da comunidade de montes de Fornelos de Montes, Carlos Pérez, Ricardo, (nese momento forestal de Fornelos de Montes), a Alex de Covelo, e a outras tantas persoas que desinteresadamente colaboraron con nós na procura dese pasado na serra.

Á miña familia. A Pedro, aínda que non o creas sempre ves comigo.

\section{BIBLIOGRAFÍA}

AYÁN VILA, X. M. e AMEIXEIRAS SÁNCHEZ, F. 2002. «Mámoas, castros e tesouros: a murindá nas terras de Cuntis». Pasado e futuro de Castrolandín (Cuntis) unha proposta de recuperación e revalorización. Xurxo Ayán Vila, (Cood.). En TAPA (Traballos en Arqueoloxía da Paisaxe) 29, Santiago de Compostela.

AGUIRRE BAZTÁN, Á. 1995, «Etnografía». Etnografia. Metodología cualitativa en la investigación sociocultural. Barcelona: Editorial Boixareu Universitaria.

ARMESTO, J. 2003, «Pedra e tella na era dixital», La Voz de Galicia, -Culturas.

BALLESTEROS ARIAS, P. 2003. «La Arqueología en la gasificación de Galicia 17: el paisaje agrario». En CAPA (Cadernos de Arqueoloxía e Patrimonio) 18, Santiago de Compostela.

BEJARANO GALDINO, E. 1986. Los chozos: una arquitectura peculiar del Suido. Cuadernos do Seminario de Sargadelos, 48. Sada, A Coruña: Edicións do Castro.

CAEIRO GONZÁLEZ, E; Vázquez Cernadas, M. Coord. 1993. Galicia pueblo a pueblo. La Voz de Galicia S.A.

CALVO, A. 2001. «Elurzulo, o como nuestros antepasados conservaban el hielo». Aranzadiana. Aranzadiko Berriak 171-172. Donostia. San Sebastián.

CARDESÍN, J. M. 1990. Tierra, trabajo y reproducción social en una aldea gallega (S.XVIII- XX): Muerte de unos, vida de otros. Serie Estudos. Ministerio de Pesca, Agricultura y Alimentación. Secretaría General Técnica.

CRIADO BOADO, F. 1999. Del Terreno al espacio: Planteamientos y Perspectivas para la Arqueología del Paisaje. En CAPA (Criterios e Convencións en Arqueoloxía da Paisaxe) 6, Santiago de Compostela.

CRIADO BOADO, F. e BALLESTEROS ARIAS, P. 2002. «La arqueología rural: contribución al estudo de la génesis y evolución del paisaje tradicional», I Congreso de Ingeniería Civil, Territorio y Medio Ambiente I, Madrid, 461-479.

FERNÁNDEZ DE ROTA, J. A. 1984. Antropología dun viejo paisaje gallego. Centro de Investigaciones Sociológicas. Madrid: Siglo XXI, S. A.

FERNÁNDEZ MIER, M. 1999. Génesis del Territorio en la Edad Media. Arqueología del paisaje y evolución histórica en la montaña asturiana. Universidad de Oviedo. 
FERNÁNDEZ PINTOS, J. 2004. La Portela da Cruz (Barcia do seixo, A Lama). Trisquel http:// usuarios.lycos.es/jufp/cruz-Portela.html

FIDALGO SANTAMARIÑA, X. A, 2002. Os saberes tradicionais dos galegos. Vigo: Editorial Galaxia.

FILGUEIRA VALVERDE, J. e GARCÍA ALÉN, A. 1959. «Adiciones a la carta arqueológica de la provincia de Pontevedra», XIII: 29. Pontevedra.

FILGUEIRA VALVERDE, J. e GARCÍA ALÉN, A. 1977. Inventario de monumentos megalíticos. Fundación Pedro Barrié de la Maza. XXXI.

GONZÁLEZ ALCANTUD, J. A. 1995. «Oralidad: tiempo, fuente y transmisión», Etnografía. Metodología cuantitativa en la investigación sociocultural. Barcelona: Antropos.

GONZÁLEZ PÉREZ, C. 2003. Xaquín Lorenzo Fernández «Xocas» 1907-1989, A Coruña: Editorial Toxosoutos.

GONZÁLEZ REBOREDO, X. M. 1993. Lendas Galegas de tradición Oral. 3 ed. Vigo: Ed. Galaxia.

GONZÁLEZ REBOREDO, X. M. 1999 «Don Xaquín Lorenzo Fernández e os estudos de etnografía en Galicia», Raigame 9. Ourense, 57-67.

GONZÁLEZ RUIBAL, A. 1998. Etnoarqueología de los abandonos en Galicia. El papel de la cultura material en una sociedad agraria en crisis. Revista Complutum, $\mathrm{n}^{\circ}$ 9. Madrid: Servicio de Publicaciones. Ed. Complutense.

LORENZO FERNÁNDEZ, X. 1947. Antiguas habitaciones de pastores en la Sierra de Leboreiro. Cuadernos de Estudos Gallegos, 7: 23. Santiago de Compostela.

LORENZO FERNÁNDEZ, X. 1959. «O pastoreo na Serra de Leboreiro». Actas do Coloquio de estudis etnográficos Dr. José Leite de Vasconcelos. Vol. I. Porto.

LORENZO FERNÁNDEZ, X. 1962. Etnografía. Cultura material. Historia de Galiza. O Home. T.II. Buenos Aires: Editorial Nos.

FERNÁNDEZ SENDÍN, M. 1995. A Graña y los grañudos. Estudo histórico antropológico. Pontevedra.

PÉREZ ALBERTI, A. 1986. A Xeografía. O espacio xeográfico e o home. Vigo: Biblioteca Básica da Cultura Galega.

RISCO, V. 1962. Etnografía. Cultura espiritual. En R. Otero Pedrayo (d.) Histboria de Galiza. O Home. T.I. Buenos Aires: Editorial Nos.

RIVAS QUINTAS, E. 1996. Millo e hórreo. Legumia e cestos. Santiago de Compostela: Edicións Laiovento.

RODRÍGUEZ, E. 1996. «Os chozos». Raigame, 2. Deputación de Ourense, 33-37

TRÍAS MERCANT, S. 1995. Los documentos y la cultura material. Etnografia. Metodología cualitativa en la investigación sociocultural. Barcelona: Editorial Boixareu Universitaria.

VÁZQUEZ VARELA, J. M. 2000. Etnoarquología: conocer el pasado por medio del presente.Vigo: Servicio de Publicacións. Deputación Provincial de Pontevedra.

VEIGA DE OLIVEIRA, E.; GALHANO, F. e PEREIRA, B. 1994. Construções Primitivas em Portugal. Lisboa: Publicacións Dom Quixote.

Cuadernos de Estudios Gallegos, Tomo LI, Fascículo 117, Santiago 2004. (Págs. 9 - 48) 